\title{
Impact of agricultural land use in Central Asia: a review
}

\author{
Ahmad Hamidov ${ }^{1,2,3}$ - Katharina Helming ${ }^{2,4}$ - Dagmar Balla ${ }^{2}$
}

Accepted: 5 September 2015 / Published online: 7 January 2016

(C) INRA and Springer-Verlag France 2015

\begin{abstract}
Agriculture is major sector in the economy of Central Asia. The sustainable use of agricultural land is therefore essential to economic growth, human well-being, social equity, and ecosystem services. However, salinization, erosion, and desertification cause severe land degradation which, in turn, degrade human health and ecosystem services. Here, we review the impact of agricultural land use in the five countries of Central Asia, Kazakhstan, Kyrgyzstan, Tajikistan, Turkmenistan, and Uzbekistan, during 2008-2013 in 362 articles. We use the Land Use Functions framework to analyze the type and relative shares of environmental, economic, and social topics related to agricultural land use. Our major findings are (1) research on land use in Central Asia received high levels of international attention and the trend in the number of publications exceeded the global average. (2) The impacts of land use on abiotic environmental resources were the most explored. (3) Little research is available about how agricultural land use affects biotic resources. (4) Relationships between land degradation, e.g., salinization and dust storms, and human health were the least explored. (5) The literature is dominated by indirect methods of data analysis, such as remote
\end{abstract}

Ahmad Hamidov

ahmad.hamidov@gmail.com

1 Humboldt-Universität zu Berlin, Philippstr. 13, 10099 Berlin, Germany

2 Leibniz Centre for Agricultural Landscape Research (ZALF e.V.), Eberswalder Straße 84, 15374 Müncheberg, Germany

3 Tashkent Institute of Irrigation and Melioration (TIIM), Kary-Niyaziy 39, 100000 Tashkent, Uzbekistan

4 University for Sustainable Development, Schickler Straße 5, 16225 Eberswalde, Germany sensing and mathematical modeling, and in situ data collection makes up only a small proportion.

Keywords Central Asia · Land Use Functions · Agriculture · Sustainable land use $\cdot$ Research gaps $\cdot$ Salinization $\cdot$ Human health

Contents

1 Introduction

2 Methodology

2.1 Study area

2.2 Land Use Functions: a framework for analyzing sustainable development

2.3 Database search

3 Results and discussion

4 Conclusion

Acknowledgments

5 References

6 References of the meta-analysis

\section{Introduction}

Central Asia is geopolitically and strategically important because of its geographic position. The Central Asian states Kazakhstan, Kyrgyzstan, Tajikistan, Turkmenistan, and Uzbekistan are situated in the heart of the Eurasian continent and form a trade link between China, the Middle East, and Europe (Liu 2011). Upon entering into membership in the Shanghai Cooperation Organization, this region has been viewed as a new route of multilateral partnership between the political powers of Russia and China (Wilhelmsen and Flikke 2011). The region is strategically important in the global economy, especially for trading carbon credits (Lal 2007) 
and exporting natural resources (oil, gas, energy, gold, and minerals). All five countries became independent from the Soviet Union in 1991, and they share a culture and a way of life that incorporate elements from both the East and the West (Olcott 1996). Prior to independence, these countries were socio-economically interdependent within the centrally planned Soviet economy. Agriculture was one of the major economic sectors of the Central Asian countries and accounted for 10 to $45 \%$ of their gross domestic product (GDP), employing 20 to $50 \%$ of the labor force (Qushimov et al. 2007). To date, agriculture remains an important sector in the economy of Central Asia, contributing 5.2 \% of the GDP in Kazakhstan, $7.5 \%$ in Turkmenistan, $18.5 \%$ in Uzbekistan, $20.8 \%$ in Kyrgyzstan, and $23.3 \%$ in Tajikistan (Abdullaev 2014; Bobojonov and Aw-Hassan 2014).

Because of the massive extraction of irrigation water for agriculture from the Amudarya and Syrdarya Rivers, the two primary rivers in this region, the ecological conditions around the Aral Sea have deteriorated. Elevated water tables associated with decades of heavy irrigation water use as well as insufficient drainage have led to the secondary salinization of croplands and watercourses (Fig. 1). Major waterlogging problems resulted in a decline in the production of cotton and wheat, which are the primary agricultural crops in the region (Toderich et al. 2002; Hamidov et al. 2007a; Sugimori et al. 2008; Varis 2014). Land salinization now affects over $47.5 \%$ of the irrigated lands of Central Asia (with $33 \%$ of irrigated lands affected in Kazakhstan, $11.5 \%$ in Kyrgyzstan, $16 \%$ in Tajikistan, $95.9 \%$ in Turkmenistan, and $50.1 \%$ in Uzbekistan). Salinization is thus a threat that is leading to declining crop production (van Dijk et al. 1999; Bucknall et al. 2003; Kushiev et al. 2005).

The advancing desertification and soil degradation of the Aral Sea in Kazakhstan's and Uzbekistan's territories have further impeded the region's sustainable land use (Indoitu et al. 2012). The increased dust storms in the Aral Sea area, particularly in the southwestern region of Uzbekistan,

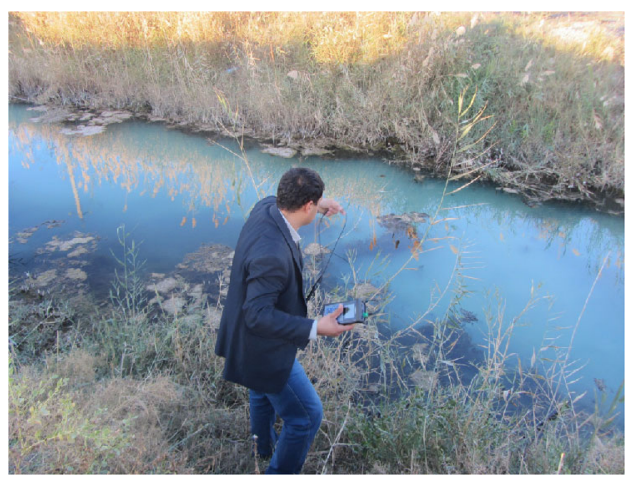

Fig. 1 Heavily salinized drainage collector characterized by the milky blue color of the water. The man is measuring the degree of salinization by electro-conductivity (Photo: D. Balla) represent a challenge impacting human health (Groll et al. 2013). Some authors report that the worsening ecological situation in the Aral Sea zone has led to a prevalence of anemia and restrictive pulmonary dysfunction, as well as a high risk of developing urolithiasis in adults and increased infant mortality (Kaneko et al. 2002; Kunii et al. 2003; Crighton et al. 2011; Groll et al. 2013).

The $1-2{ }^{\circ} \mathrm{C}$ increase in the temperature that has occurred in Central Asia since the beginning of the twentieth century has led to impacts on agricultural production and land use practices (Lioubimtseva et al. 2005; Fischer et al. 2002). Climate warming is expected to aggravate the situation, resulting in decreasing snow and glacier reserves in the Tien Shan and Pamir Mountains, which are the only source of water for most of the irrigated croplands in the region (Aleksandrova et al. 2014). Transboundary water management conflicts have resulted in a decline in crop production (Rakhmatullaev et al. 2010a). The ongoing dispute between agriculture and hydropower with regards to water use has implications for the region's sustainable development (Libert and Lipponen 2012). Varis (2014) noted that Central Asian countries have plenty of water relative to their populations but have a very low economic return on water compared with other parts of the world. For instance, Turkmenistan uses almost three times more water than India to produce one GDP dollar (Varis 2014; World Bank 2013). Some authors suggested that one way to achieve long-term sustainability in terms of agricultural land use in Central Asia was to switch from growing low-return crops on irrigated dry lands to a less water-intensive crop production system (Hamidov et al. 2007b; Bobojonov et al. 2013a; Varis 2014). However, it is important to emphasize that less waterintensive crops may not necessarily cover the cost of the huge and expensive irrigation and drainage system in Central Asia, and alternative crops may be integrated into the crop rotation program of these countries. Nonetheless, prior to achieving this status, the sustainability issues must be better understood.

In addition to the thorough understanding of the drivers for land use changes, including climate change, water conflicts, and resource degradation, policy makers (international and domestic institutions) and land managers need a comprehensive knowledge base regarding the impacts of agricultural land use on environmental, economic, and social dimensions of sustainable development. Research can provide this knowledge base at the highest quality level, as is guaranteed through the international peer-review system. By performing a metaanalysis of existing scientific literature, this knowledge base can be mined, and blind spots can be detected when the data are analyzed against all three dimensions - environmental, economic, and social —of sustainability.

The primary objective of this paper was to analyze the current international literature on agricultural land use in Central Asia and its relevance to sustainable development. We applied the Land Use Functions framework (Perez-Soba 
et al. 2008) to operationalize the concept of sustainable development in the context of agricultural land use. In particular, we examined the type and relative shares of environmental, economic, and social aspects in agricultural land use that were addressed in the literature. By building upon this review, we aimed to identify existing knowledge gaps and the need for future research on sustainable land use.

\section{Methodology}

\subsection{Study area}

Central Asia, which comprises the five former Soviet Union republics of Kazakhstan, Kyrgyzstan, Tajikistan, Turkmenistan, and Uzbekistan (Fig. 2), covers an area of approximately 4 million $\mathrm{km}^{2}$ and has a total population of 65 million. These countries share their borders with China to the east, Russia to the north, the Caspian Sea to the west, and Iran, Afghanistan, and Pakistan to the south.
Central Asia is a dryland region, and the climate is continental with hot summers and cold winters (Mueller et al. 2014), particularly in the lowlands of Kazakhstan, Turkmenistan, and Uzbekistan. Kyrgyzstan and Tajikistan are located in the mountainous areas of Tien Shan and Pamir, respectively, with large differences in climatic conditions between the mountains and valleys. Approximately $90 \%$ of Central Asia's area receives less than $400 \mathrm{~mm}$ of rainfall per year: $191 \mathrm{~mm}$ in Turkmenistan, $264 \mathrm{~mm}$ in Uzbekistan, $344 \mathrm{~mm}$ in Kazakhstan, $533 \mathrm{~mm}$ in Kyrgyzstan, and up to $691 \mathrm{~mm}$ in the mountainous region of Tajikistan (Mueller et al. 2014). The annual potential evapotranspiration in the lowlands exceeds the annual rainfall, and thus, irrigation is required to cultivate agricultural crops.

Agricultural land covers approximately 2.8 million $\mathrm{km}^{2}$ or $70 \%$ of the total land area (Lal 2007). Approximately 2.5 million $\mathrm{km}^{2}$ or $63 \%$ of the total land is in rangelands, whereas approximately 0.3 million $\mathrm{km}^{2}$ or $7 \%$ are croplands. Notably, of the 0.3 million $\mathrm{km}^{2}$, only 0.1 million $\mathrm{km}^{2}$ is under irrigation (Mueller et al. 2014). The irrigated land in Central Asia expanded dramatically during the Soviet Union's active years,

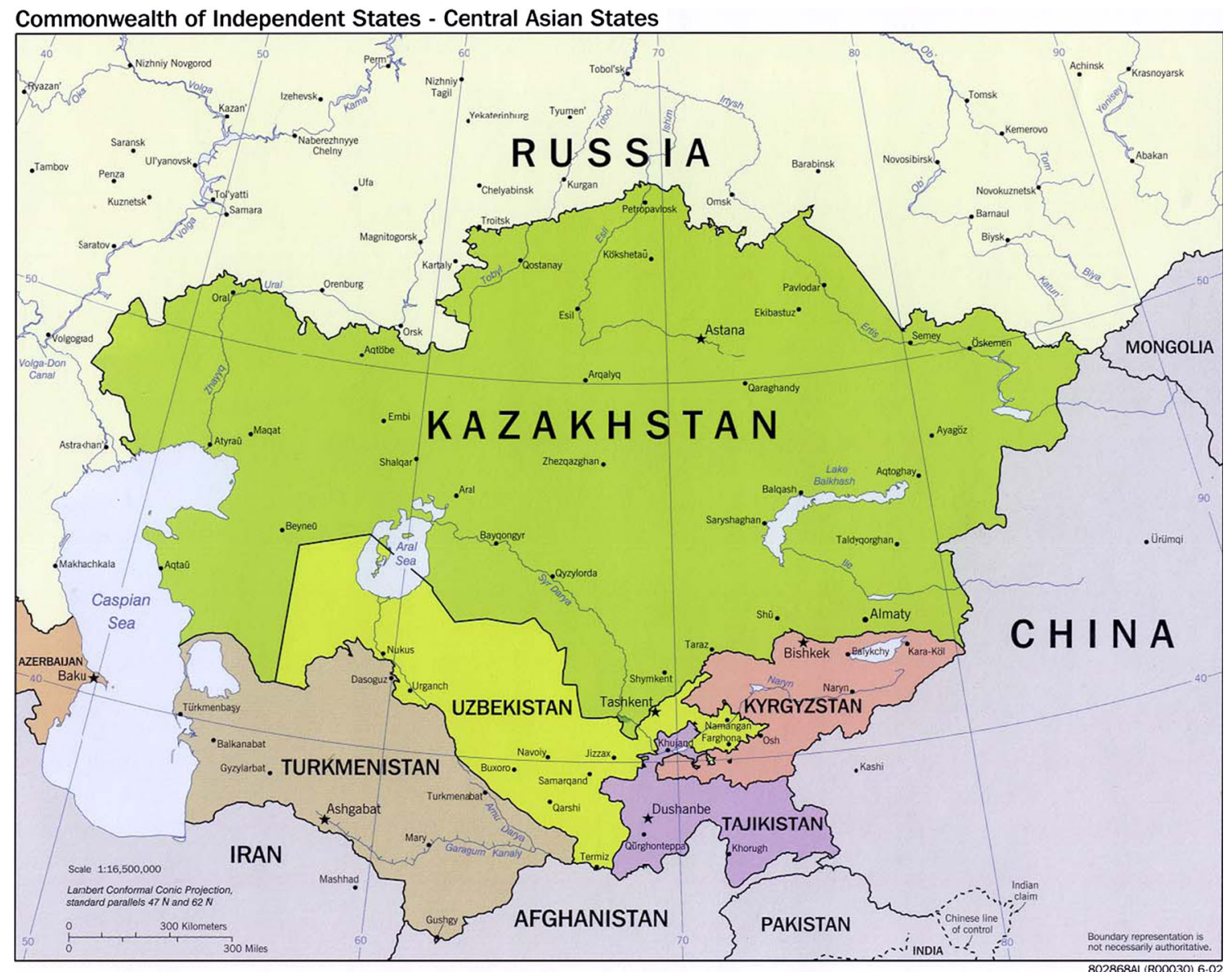

Fig. 2 Map of the five countries of Central Asia, which are surrounded by China, Russia, Afghanistan, Iran, Pakistan, and Azerbaijan (retrieved from: $\mathrm{http}: / /$ origins.osu.edu/article/69/maps). The total agricultural land in Central Asia is 2.8 million $\mathrm{km}^{2}$. Kazakhstan has the largest territory in the region 
particularly in Uzbekistan, where the irrigated area tripled from 0.14 to 0.42 million $\mathrm{km}^{2}$ between the $1950 \mathrm{~s}$ and 1990 (Khamraev et al. 2011).

The agricultural sector in Central Asia is undergoing reorganization. According to Suleimenov (2014), the following changes were made: During the time of the Soviet Union, each country specialized in certain agricultural strategies, with Kazakhstan in grain production; Kyrgyzstan in sheep production, alfalfa, and maize; and Tajikistan, Turkmenistan, and Uzbekistan producing as much irrigated cotton and karakul sheep for pelts as possible. During the transition time that followed, the development of the crop production industry began. In Kazakhstan, the cropland area was reduced significantly, and monoculture wheat production followed, with producers recently beginning to include food legumes such as dry peas and chickpeas. Kyrgyzstan specialized in alfalfa seed, potatoes, and maize. During the transition period, the wheat area was doubled. Dry beans under irrigation are now increasing in the current market economy. Tajikistan previously specialized in cotton production. The wheat area has doubled but has a low yield level. Turkmenistan now produces bread wheat at a respectable level, although this level is low for irrigated land. In Uzbekistan, self-sufficiency in bread wheat grain has been a major achievement of agricultural restructuring in recent years. Thus, the area under cotton has been reduced, and alfalfa and other forage crops have been removed from irrigated land. A cotton-alfalfa rotation has been replaced by a cotton-wheat rotation. Livestock and forage production has decreased in most Central Asian countries to a negligible level. However, the demand for food and forage is increasing. Poorly managed rangelands lead to a lack of feed, land degradation, a loss of plant biodiversity, and expanding desertification (Gintzburger et al. 2003). Consequently, researchers are now demanding a change in policies towards the support of rangeland improvement and integrated crop and livestock production (Suleimenov 2014).

With the exception of Kazakhstan, the primary water resources of the Central Asian countries are the melting waters of the Tien Shan and Pamir Mountains, which form the Syrdarya and Amudarya Rivers. Turkmenistan and Uzbekistan are extremely dependent on water resources that come primarily from Kyrgyzstan and Tajikistan. Thus, water distribution is a top political issue and novel methods and knowledge-based developments at a rural scale are necessary to overcome water scarcity and match the rising economic status of the area.

\subsection{Land Use Functions: a framework for analyzing sustainable development}

Since the Brundlandt Report, sustainable development has become a paradigm for policy making worldwide (WCED 1987). Decision-making that is oriented towards sustainable development requires knowledge and the simultaneous consideration of ecological, economic, and social dimensions. In the case of land use, the Land Use Functions framework helps to make the concept of sustainable development tangible and operational (Helming et al. 2011a). Land Use Functions are defined as "the goods and services provided by different land uses that summarize the most relevant environmental, economic and societal issues of a region" (Perez-Soba et al. 2008). The concept was developed to substantiate the concept of sustainable development with the concept of multifunctional land use and thereby simultaneously consider environmental, economic, and social aspects. This facilitates the assessment and governance of land use to promote sustainable development (Helming et al. 2011a).

The framework is designed such that for each of the three sustainability pillars, three categories are defined that together cover all the important functions of land use. The outcome is nine categories of so-called Land Use Functions: environmental: (1) abiotic, (2) biotic, and (3) ecosystem processes; economic: (4) land-based production, (5) market, and (6) transport/infrastructure; and social: (7) employment, (8) health, and (9) culture. Those nine function categories are generic and must be particularized according to the specific spatio-temporal and sustainability context to which they are applied. For instance, in China, food access and quality were identified as the primary issues related to social Land Use Function 8, namely "health" (König et al. 2014a), and in Europe, this function was related to recreation (Perez-Soba et al. 2008). When determined using adequate indicators and ranked in their relative importance for region-specific sustainable development, the Land Use Functions can be combined to support and evaluate policies (Paracchini et al. 2011). This framework has been applied for sustainability assessments and land use classification in China (Xie et al. 2010; König et al. 2014a), India (Purushothaman et al. 2013), various developing countries (König et al. 2013), and Europe (Helming et al. 2011b; Morris et al. 2011). The framework was also used in a literature review of sustainability issues related to land use in Inner Mongolia, China (König et al. 2014b). This scheme has yet to be applied to the context of Central Asian sustainable agricultural land use, and thus, we used Land Use Functions as the analytical framework for the literature analysis in this study.

\subsection{Database search}

We included scientific publications that addressed agricultural land use in Central Asia. A systematic database search of peerreviewed articles was conducted using the electronic Web of Science. We selected only the international journal articles that stayed within the boundaries of internationally acceptable scientific quality management. This approach leaves out the analysis of, e.g., research results published in national 
publication formats, which might also be of very high information level. However, language barriers and the inaccessibility of "gray" literature created difficulty in the comprehensive analysis of the existing literature on agricultural land use.

All analyses were conducted between July and October 2014. The logic of our analysis was to view agricultural land use as the cause (pressure) and Land Use Functions as effects (impact). We therefore selected search terms that were relevant to agricultural land use and to Central Asian countries. The following thematic search terms were used: agriculture, farm, irrigation, land, land use, and water management. For geographic search keywords, we used Kazakhstan, Kyrgyzstan, Tajikistan, Turkmenistan, Uzbekistan, and Central Asia. The composite terms were placed inside inverted commas, and an asterisk was used at the end of each term capture all possible extensions and variations of a particular word. The documents were considered relevant if they matched at least one of the topical search terms and one of the geographic search terms in their titles, abstracts, or keywords.

The study period covered the 6 years from 2008 to 2013 . The selection of this study period was driven by two considerations. First, the severe re-organizations of agricultural land use after independence required some time to settle before sustainability impacts could be analyzed. Second, there was a need to balance the comprehensiveness of the sampling and the workability within a reasonable time period. We selected this study period after first conducting an automated database search with the same search terms for the 1991-2013 time period to cover the entire period since independence. The results showed that almost two thirds (62\%) of the papers were published after 2008. We therefore selected 2008 as the starting year for the analysis. This year also coincides well with the publication date of the Land Use Functions framework by Perez-Soba et al. (2008), which we used for the analysis.

To compare the dynamics of agricultural land use publications in Central Asia with global dynamics, we also performed an automated database search using the same thematic terms for worldwide publications on agricultural land use during the same time period from 2008 to 2013.

After identifying the relevant papers, we reviewed all abstracts; in the case of irrelevance to the research region or agricultural land use, the papers were discarded from the database. Relevance was checked on the basis of Land Use Function categories, and papers were then assigned to one or several of the nine Land Use Function categories. The original definitions of Land Use Functions were specified in accordance with the regional and sustainability context of our research question (Table 1). For instance, the provision of abiotic resources related to land use concentrated primarily on the physical and chemical properties of soil and water resources (Land Use Function 1), whereas the maintenance of ecosystem processes was related to ecological issues, land degradation, and grassland management (Land Use Function 3 ). The former addressed more technical aspects of research related to the environment, and the latter was more concerned with the broader aspects of environmental improvements. Last but not least, the support and provision of biotic resources were relatively focused on habitats for fauna and flora, as well as other living organisms (Land Use Function 2).

Under the economic dimension of sustainability, the study captured research related to land-based production such as crop yields, value-added chains, and biomass production (Land Use Function 4). The provision of financial services and access to rural banks for agricultural farm management, as well as land competition associated with agriculture, were coded under Land Use Function 5, "market- and landindependent production." Research on the implementation of large-scale irrigation projects, the management of physical infrastructure, and issues related to transboundary water conveyances in relation to land use practices were included under Land Use Function 6, "transport/infrastructure."

Finally, the social aspect of sustainability included the provision of job opportunities, income, and livelihood security in rural areas (Land Use Function 7), as well as concern about health-related diseases and malnutrition in the region (Land Use Function 8). The use of these landscapes for cultural heritage and the gender issues involved in accessing agricultural land were the primary concerns of Land Use Function 9.

To reveal the types of scientific methods used, we further analyzed the research methods of each paper. After a detailed review of each paper, we divided them into two categories: direct data analysis (stakeholder-involved analysis, monitoring, and in situ experiments) and indirect data analysis (including geographic information systems (GIS), remote sensing, modeling, and review analysis). Finally, the authors' institutional affiliations were examined to determine which countries had been active with respect to agricultural land use research in Central Asia during the study period.

\section{Results and discussion}

The automated database search returned a total of 697 papers. Of these, we found 362 articles (52\%) that were relevant to agricultural land use in Central Asia. The other 335 articles were removed from the database because of their irrelevance to the geographic area or to agricultural land use. For instance, some papers referred to the eastern part of China (Xinjiang), Afghanistan, and Mongolia as Central Asia. Additionally, some papers referred to the thematic search terms we used in the abstract, but the detailed review of the abstract and, in some cases, the whole paper indicated its irrelevance to agricultural land use. Those papers were thus omitted. We noticed an annual increase in the number of selected publications 
Table 1 Land Use Functions used in this study

\begin{tabular}{lll}
\hline Land Use Functions & Definitions & Adapted to the study \\
(LUFs) &
\end{tabular}

Environmental dimension

LUF 1: Provision of abiotic The role of land use in regulating the supply and quality of resources

LUF 2: Support and provision of biotic resources

LUF 3: Maintenance of ecosystem processes

Economic dimension

LUF 4: Land-based production

LUF 5: Market and landindependent production

LUF 6: Transport/ infrastructure

Social dimension

LUF 7: Provision of work

LUF 8: Human health and recreation (spiritual and physical)

LUF 9: Cultural (landscape identity, scenery, and cultural heritage) air, water, minerals, and soils

Physical and chemical properties of soils, water and air quality, water, and soil pollutants

The role of land use in regulating the capacity of the land to Habitats for fauna, flora, and other organisms support biodiversity, in terms of the genetic diversity of organisms and the diversity of habitats

The role of land use in the regulation of ecosystem processes Ecosystem services, land degradation, soil fertility, and related to the production of food and fiber, the hydrological cycle and nutrient cycling, cultural services, and ecologically supportive functions, such as soil formation and carbon sequestration
The role of land use for production activities that do not result Crop yields, value chains, and biomass production in irreversible change, e.g., agriculture, forestry, renewable energy, and land-based industries, such as mining

The role of land use in residential, social, and productive human activity occurring in a concentrated fashion. The utilization of this space is largely irreversible because of the nature of the activities

The role of land use in the provision of space used for roads, Implementation of large-scale water projects, management railways, and public transport services, which involve development that is largely irreversible of irrigation infrastructure, and issues related to the transboundary water conveyances

Provision of job opportunities, income, and livelihood security security, and the location of jobs (constraints, e.g., daily commuting)

The role of land use in health and recreational services and factors that influence service quality

Human health, nutrition, and food security

The role of land use for landscape aesthetics and quality and values associated with local culture

The use of the landscape for cultural heritage and diversity purposes. The issue of gender in land access

Adapted from Perez-Soba et al. (2008)

during the study period, indicating that researchers were paying increasing attention to agricultural land use in Central Asia (Fig. 3). The increase in the number of annually published papers on that topic was $67 \%$ in Central Asia over the 6year period, compared with $48 \%$ worldwide (Fig. 3). The trend in Land Use Function-related papers was higher in Central Asia than in the rest of the world.

Most of the papers deal with some aspects of the environment associated with agricultural land use, which confirms the critical role of agriculture for environmental degradation in Central Asia, e.g., the drying up of the Aral Sea (Dukhovny and Stulina 2001; Crighton et al. 2011). The distribution of publications across nine Land Use Function categories is given in Fig. 4. Notably, each paper could be allocated to more than one Land Use Function. Of the 362 papers analyzed, the environmental aspects of land use were most often addressed (422 times), followed by the economic aspects of land use (270 times). The social aspects of land use were least often addressed (101 times).

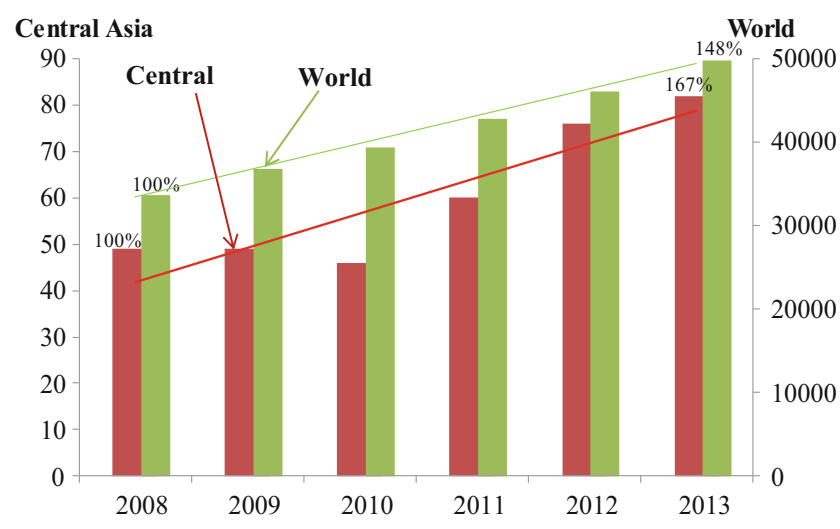

Fig. 3 Number of articles on Land Use Functions in Central Asia and the world, by year, from 2008 to 2013 . Of the 362 papers that were found to be relevant to agricultural land use in Central Asia, almost half were published in the most recent 2 years (2012 and 2013), indicating the overall increase in the attention paid to the region. This increase is larger than that of the world as a whole 


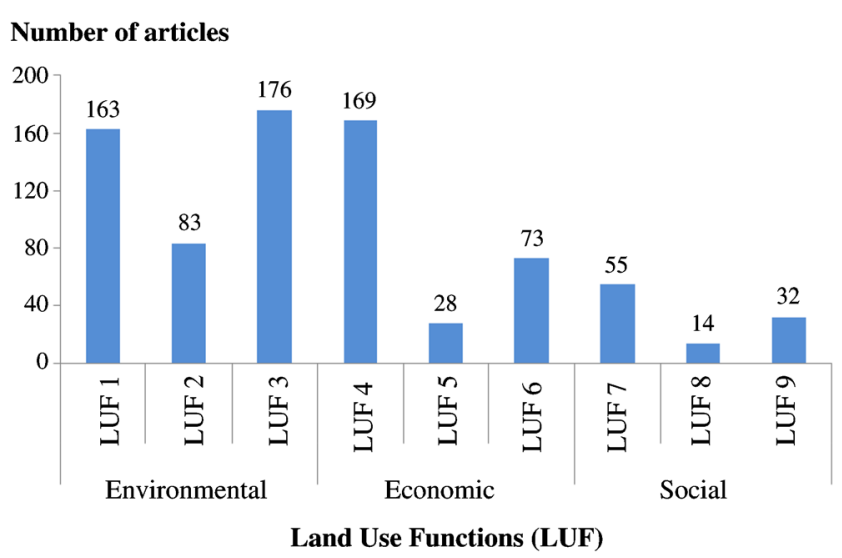

Fig. 4 Distribution of Land Use Functions addressed in peer-reviewed publications that focused on Central Asia (LUF 1: provision of abiotic resources, $L U F$ 2: support and provision of biotic resources, $L U F 3$ : maintenance of ecosystem processes, $L U F$ 4: market and land-based production, $L U F$ 5: residential and land-independent production, $L U F$ 6: transport/infrastructure, $L U F$ 7: provision of work, $L U F$ 8: human health and recreation, and $L U F$ 9: culture)

Among the environmental aspects, the provision of abiotic resources and the maintenance of ecosystem services were most addressed. One hundred sixty-three articles (45 \%) addressed the physical and chemical properties of soil and water quality in relation to agronomic activities, including the salinization of irrigated fields, particularly in Kazakhstan, Turkmenistan, and Uzbekistan. The largest number of papers (almost $50 \%$ of the articles) raised concerns regarding ecosystem maintenance and addressed issues related to croplands and grasslands, ecology, and land degradation. The support and provision of biotic resources were least explored within the environmental dimensions of sustainability ( $23 \%$ of papers). When addressing soil salinity, heavy metal analyses in the soils, and the regulation of water contamination through agricultural runoff, papers also targeted ecosystem services, the improvement of soil and land, and grassland management. We found that 117 papers discussed some aspects of abiotic resources and ecosystem maintenance simultaneously, thereby making use of a broader approach to ecosystem services. In terms of the support and provision of biotic resources with regards to habitats for fauna and flora and other organisms associated with the land capacity, we identified 35 papers that also addressed the economic dimension of agricultural land use, particularly land-based production. Here, the primary issue was the analysis of trade-offs between agronomic performance and biodiversity issues.

Among the economic factors, papers mostly addressed land-based production such as crop yields, value-added chains, and biomass production-related research $(47 \%)$, followed by water infrastructure $(20 \%)$. In the latter case, the reconstruction and rehabilitation of on-farm and interfarm irrigation and drainage infrastructures were the primary concerns of most papers. Land-independent production, market mechanisms, financial services, and property rights issues played a minor role in the literature. Of the 362 papers, only 28 articles, corresponding to $7 \%$, addressed these issues. Dear et al. (2013) argued that in the context of Central Asia, researchers who address the socio-economic aspects of agriculture often do not include any connection to land use, land management, or ecosystem services.

When comparing the distribution of publications on the economic versus social dimensions of sustainable development, social sciences were underrepresented. The World Bank (2006) emphasized that the technical aspects of land management are more locally relevant in Central Asia once the basic "institutional" constraints are resolved. Among the publications that address the social aspects of land use, the highest number (55) addressed the provision of job opportunities for rural inhabitants, income, and livelihood security in relation to agricultural land use. Thirty-two articles presented research on the use of the landscape for cultural heritage and diversity purposes. Although the people in the region are experiencing significant health problems resulting from soil salinization and land degradation (Groll et al. 2013), only 14 articles $(4 \%)$ addressed the impacts of land use and degradation on human health. A detailed review of the health-related papers indicated that only three papers discussed some aspects of human health and recreational services in the Aral Sea areas of Central Asia. Of these, Bhaduri and Kloos (2013a) explored whether the water fees that were collected by a water users' association can be used to provide socio-economic benefits to its members. These benefits included the maintenance of health centers and schools and the provision of microcredit (Bhaduri and Kloos 2013a, b). Oberkircher et al. (2011a) explored the importance of the ecological and socio-cultural dimensions of Shurkul Lake, which was formed by transforming a forested landscape to an agricultural landscape. The results indicated that "the lake is part of local ecological knowledge, functions as a prestige object and recreational site, and is rooted in the religious beliefs of the population as a symbol of God's benevolence" (Oberkircher et al. 2011a, b). Franz et al. (2010) assessed the economic viability of organic cotton produced in Uzbekistan. Their study compared a conventional cotton production system, which contributed to soil degradation, water depletion, and poor human health, with an integrated organic system in Western Uzbekistan. The results revealed that the higher profits achievable under an organic farming system could reduce the pressure on the environment and improve local livelihoods (Franz et al. 2010). Despite these three examples, the scientific evidence base related to the social aspects of land use is very limited, although it is of high societal relevance, particularly regarding the direct effects of salinization and dust storms on human health (Groll et al. 2013). This scientific base is also limited because the interactions between land use and human health are not always explicitly discussed. For instance, Crighton et al. (2011) concluded that human health problems were directly 
affected by the environmental disaster in the vicinity of the Aral Sea. However, the link with the land use was not explicitly described.

We analyzed the number of papers that covered more than one sustainability dimension to identify the prevalence of the use of an integrated, sustainability-related approach among these publications. One hundred and sixty-seven papers (approximately $46 \%$ ) addressed the Land Use Functions of at least two of the three dimensions of sustainable development. However, only 26 papers (approximately $7 \%$ ) covered all three dimensions of sustainable development simultaneously, meaning that these papers addressed at least one Land Use Function category from each dimension of sustainable development (environmental, economic, and social).

The distribution of the Land Use Functions across different countries is given in Fig. 5. The country rankings in terms of the number of publications that cover different types and relative shares of Land Use Functions were led by Uzbekistan (first), followed by Kazakhstan (second). At first glance, this result is surprising because the agricultural land area in Kazakhstan is 2.1 million $\mathrm{km}^{2}$, which is eight times larger than the agricultural land area in Uzbekistan (0.26 million $\mathrm{km}^{2}$ ) (FAO 2012). However, agricultural land use in Kazakhstan is extensive and is associated with low resource input. Another reason for this finding might be the rigorous renouncement of irrigated agriculture in parts of Kazakhstan within the Aral Sea watershed. Thus, conflicts between

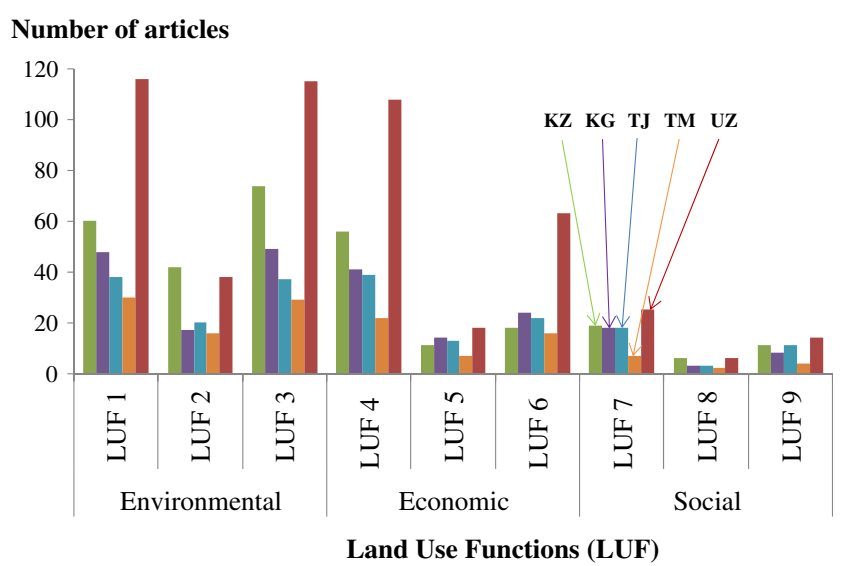

Fig. 5 Distribution of articles for each Land Use Function across the countries of Central Asia. Social issues related to land use are underexplored. This deficiency is particularly severe for the relations between land use and health issues. The implications of land use for biodiversity have been rarely studied. Instead, the focus has been on non-biotic environmental impacts. Of the five countries, Uzbekistan has been addressed most often. The ranking of the bars is as follows: Kazakhstan $(K Z)$, Kyrgyzstan $(K G)$, Tajikistan $(T J)$, Turkmenistan $(T M)$, and Uzbekistan (UZ). (LUF 1: provision of abiotic resources, $L U F$ 2: support and provision of biotic resources, $L U F$ 3: maintenance of ecosystem processes, $L U F$ 4: market and land-based production, $L U F$ 5: residential and land-independent production, $L U F$ 6: transport/ infrastructure, $L U F$ 7: provision of work, $L U F 8$ : human health and recreation, and $L U F$ 9: culture) agriculture and the water management of the Aral Sea have been settled and thus do not require further scientific consideration. However, no research was found addressing the accompanying monitoring of ecological, economic, and social themes.

High-intensity, irrigated agriculture is more dominant in Uzbekistan ( 0.42 million $\left.\mathrm{km}^{2}\right)$ than in Kazakhstan ( 0.21 million $\mathrm{km}^{2}$ ) (Kienzler et al. 2012). Highly intensive agriculture is usually associated with a higher research input than lowintensity agriculture. In addition, Uzbekistan benefited from an extensive German research project on land and water resources that involved both local and international scholars. The project was implemented through the Center for Development Research (ZEF) at the University of Bonn from 2000 to 2011, with financial assistance from the German Ministry of Education and Research. In addition, the Central Asian office of the International Water Management Institute (IWMI) in Tashkent has been very active since the beginning of 2000 in promoting research activities in three countries of the Ferghana Valley (namely, Kyrgyzstan, Tajikistan, and Uzbekistan) to implement an integrated water resource management approach. Turkmenistan also has a considerable share of irrigated cropland with 0.18 million $\mathrm{km}^{2}$ (Kienzler et al. 2012), but there are few research papers relevant to this country (Fig. 5). When considering the relative shares of Land Use Functions per country, Fig. 5 clearly shows that papers relevant to Kazakhstan were more frequently concerned with biotic resources and biodiversity compared with other countries. This finding may be explained by the fact that much of Kazakhstan's economic growth is currently driven by the oil and gas sectors (Petrick et al. 2014), with agriculture being one of the lowest GDP contributors to the national economy of Kazakhstan. Because of this country's concern with the eradication of the Aral Sea disaster, its focus has shifted towards the restoration of wetlands and fisheries in the vicinity of the lake (World Bank 2010). Consequently, the role of land use in supporting biodiversity received more attention than economic functions.

Given the prominence of empirical papers within the literature on Land Use Functions, it is interesting to investigate the types of scientific methods used in these papers (Fig. 6). The analysis revealed that only $14 \%$ of the papers were based on direct data collection methods, including quantitative sampling and experimental methods (6\%) and qualitative, social science methods $(8 \%)$, and that $85 \%$ of the papers used indirect methods. Of these papers, more than half (52\%) employed GIS and remote sensing to analyze land-related issues. Spatiotemporal data on land use and land cover were obtained from various satellites (e.g., MODIS, Landsat, and GRACE) and were processed with GIS and remote sensing. Mathematical modeling was the second most commonly employed method in the portfolio (22\%). Agent-based modeling, farm modeling, household modeling, sector 
Fig. 6 Articles published on Land Use Functions in Central Asia by type of scientific method used from 2008 to 2013. Of the 362 papers, most $(74 \%)$ reported research that was performed with indirect methods of data analysis, namely, remote sensing and modeling. Some ground-truthing work (monitoring and experimentation on the ground) could support the proper validation of the simulated data. Literature describing this type of work is scarce

\section{Articles published (\%)}

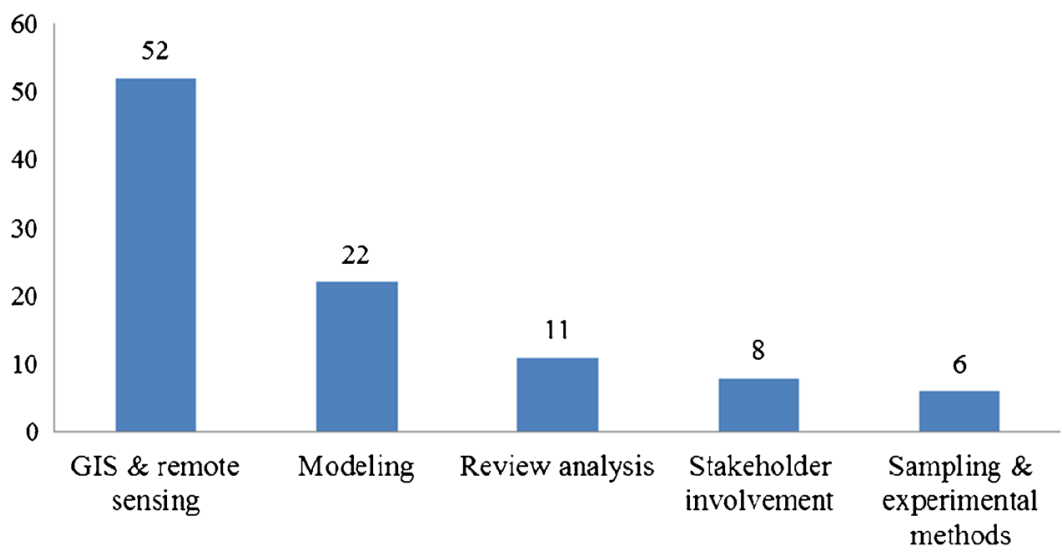

models, scenario modeling, simulations, and sensitivity analysis were also employed. Review studies constituted $11 \%$ of the publications. In comparison, in situ research by means of experiments and collecting quantitative and/or qualitative data was relatively rare. Only $8 \%$ of the papers employed stakeholder-inclusive social science methods, including expert interviews, focus group discussions, and/or participatory approaches. Sampling and experimentation were the leastpracticed methods ( $6 \%$ of publications). These results indicate that of the 362 papers, only $14 \%$ were based on in situ work (quantitative and qualitative analysis), including very little local-scale field work and bottom-up work. This distribution might be associated with a risk of data scarcity for proper ground-truthing in remote sensing and modeling work. Indeed, the risk of misinterpreting indirect and remotely sensed data is high when the in situ database for backing and validation is thin. Additionally, the preference of international authors for using indirect methods might explain the low number of papers that address biodiversity issues and biotic resources or social science issues, which are difficult to analyze with the currently available methods of mathematical modeling or remote sensing.

When author institutional affiliations were examined, we found that approximately $87 \%$ of all papers were published by international research groups. The data reveal that almost one third of the papers (135) were either individually or jointly authored by researchers affiliated with Germany. As mentioned elsewhere in this paper, this distribution is related to the long-term engagement of a German university in the region. These publications showed that the sustainable management of land and water resources in the Aral Sea area of Uzbekistan was the primary focus of the German research organization ZEF from 2000 to 2011. In particular, the ZEF project in the Aral Sea Basin was aimed at the economic and ecological restructuring of land and water use in the Khorezm region of Uzbekistan by engaging local stakeholders in designing and implementing new innovative solutions (Martius et al. 2012). Only approximately $13 \%$ of the publications were published by Central Asian authors, of which $7 \%$ consisted of IWMI publications.

In the introduction to this paper, we highlighted four key issues in sustainable development that are affected by agricultural land use in Central Asia: (a) soil salinization and land degradation, (b) transboundary water management, (c) climate change, and (d) water use efficiency and the economic return on water use. In the case of soil salinity and land degradation, these factors were mostly addressed under the environmental dimension of sustainable development in relation to abiotic resources and ecosystem maintenance, respectively. These issues were found to be critical for the sustainable development of the Central Asia region because of the worsening situation in the vicinity of the Aral Sea (Dukhovny and Stulina 2001; Crighton et al. 2011). Present transboundary disputes over water management in the region are creating an increasingly challenging situation for the governments of these Central Asian nations that poses a threat to national water security and irrigated agriculture in the region. This literature analysis reflected this challenge: of the 73 papers related to the implementation of large-scale water projects, the management of irrigation infrastructure, and issues related to transboundary water conveyances, 29 articles focused on multinational aspects of water management. For instance, Libert and Lipponen (2012) investigated issues related to transboundary water resources in Central Asia and concluded that "the outdated legal framework for regional cooperation on shared waters requires improvement to help find sustainable long-term solutions for the reasonable and equitable use of shared water resources." They highlight that reduced flows in transboundary rivers have led to land degradation and negative impact on ecosystems.

The effects of climate change in the region have adversely affected the availability of high-quality water and productive soil for agriculture (Krysanova et al. 2010; Qadir et al. 2013). Additionally, the increased frequency and intensity of droughts and floods might also be directly linked to the climate change in the region (Krysanova et al. 2010). The findings of reviews confirm the role on climate change as an 
important driver of sustainability impacts on agricultural land use. Climate change issues were at the forefront of many papers (43 papers or $12 \%$ ). This review indicated that climate change was primarily discussed in reference to water and soil quality, long-term ecosystem processes such as land degradation and grassland management and the availability of water for agriculture in the transboundary context. There was one publication by Kassam (2009) in which the author discussed the impacts of climate change on local culture, women, and sustainable livelihoods using the example of Tajikistan.

Growing competition between upstream hydropower and downstream irrigated agriculture is representative of the symptoms of water scarcity in Central Asia (Platonov et al. 2008a). Identifying approaches for the application appropriate water-saving techniques in agriculture is the key to sustainable water management in the region. Of the 28 papers that addressed the economic dimension of sustainability and market mechanisms specifically, 11 papers (representing only $3 \%$ of the sample) described some links to the economic return on water use in agriculture. These papers made scientific recommendations for shifting towards economically viable crop production. However, very few papers provided specific evidence of the economic benefits that could be achieved based on numerical data. Therefore, future research should be devoted to this particular shortcoming.

We used the Land Use Functions framework for this research review to investigate sustainability issues related to agricultural land use in Central Asia. The framework was originally designed to assess land use changes in Europe by considering the three sustainability dimensions (environmental, economic, and social) (Perez-Soba et al. 2008). Subsequently, the framework was operationalized in the context of other countries, such as China and India (König et al. 2014a; Purushothaman et al. 2013). In Central Asia, only one study assessed the state of research on sustainable land management in Kyrgyzstan and Tajikistan using the Global Land Project analytical framework (Dear et al. 2013). In that study, Dear et al. (2013) covered the post-independence period from late 1991 to mid-2012 and investigated only the international academic literature published concerning Kyrgyzstan and Tajikistan and gray literature. By covering a different timeline and the complete geographical area of Central Asia and using a different analytical framework and different publication types, the current study furthers the scientific knowledge on sustainable land use.

\section{Conclusion}

This research revealed key knowledge gaps regarding the contribution of agricultural land use to sustainable development in Central Asia. The analysis focused exclusively on Web of
Science-based peer-reviewed international journals covering the 2008-2013 period. All findings and conclusions were therefore restricted to this recent period of time and to internationally accessible publications. It is possible that earlier studies and/or domestic, non-internationally quality-validated publications contain information with the potential to fill some of the knowledge gaps identified here. However, the availability of and access to those studies represent a substantial barrier because of language concerns and non-standardized archiving methods. Given this limitation, the findings indicate that a comprehensive knowledge base is available concerning the impacts of agricultural land use on environmental issues, particularly those related to soil and water issues and to the maintenance of ecosystem processes. Little information was available about the relationships between agricultural land use and biotic resources, such as habitats for fauna and flora and other organisms. With respect to the economic aspects of agricultural land use, the research was focused on the direct economic return of biomass production and on infrastructure issues related to constructing and maintaining irrigation and drainage systems. Given that water scarcity is a key factor affecting agriculture in Central Asia, the economic returns on agricultural water use compared with those of other water uses should be emphasized in the future. The most striking finding was that very few papers addressed the impacts of agricultural land use on the societal dimension of sustainable development. This finding is in contrast to the abundant knowledge of human health concerns related to salinized water and the aspiration of dust-contaminated air. Clearly, the disciplinary research has somehow ignored the causal chain of events relating inappropriate irrigation management and water salinization to land degradation and dust storms through wind erosion. A more systemic, interdisciplinary approach to the analysis of agricultural land use impacts may help to overcome this limitation in the future.

This review revealed the underrepresentation of in situ research by means of collecting quantitative and/or qualitative data. Most papers were based on indirect research methods, such as remote sensing and mathematical modeling. Those methods also build upon a solid database for the groundtruthing of remotely sensed data and for the calibration and validation of model simulation. However, the specific understanding of the complexity of local socio-economic and political situations related to sustainable development requires indepth case study research. This direction should clearly be prioritized in future research. Finally, the papers mostly focused on arable land use issues in the region, and the inclusion of pasture or rangelands in future studies could further provide a comprehensive overview of land use practices in both the lowlands and uplands of Central Asia.

Acknowledgments Funding for this study was provided by the Leibniz Centre for Agricultural Landscape Research (ZALF) within the frame of a 
cross-disciplinary impact assessment project. Additionally, Ahmad Hamidov's research for this paper benefited from the Volkswagen Foundation within the framework of the InDeCA project (Designing Social Institutions in Transition: Promotion of Institutional Development for Common Pool Resources Management in Central Asia). The authors would like to thank the anonymous reviewers for their constructive critiques. The authors would also like to thank Jana Rummler and Claus Dalchow for their support in the Web of Science analysis and Till Hermanns, Azhar Abbas, and Carten Gutzler for their support in the data analysis.

\section{References}

Abdullaev I (2014) Water-energy-agriculture and environment nexus in Central Asia: current state and future. Presentation from the World Water Week, Stockholm, Sweden. http://programme. worldwaterweek.org/sites/default/files/water-energy-food and environmental_nexus_in_central_asia.pdf. Accessed 21 Feb 2015

Aleksandrova M, Lamers JPA, Martius C, Tischbein B (2014) Rural vulnerability to environmental change in the irrigated lowlands of Central Asia and options for policy-makers: a review. Environ Sci Pol 41:77-88. doi:10.1016/j.envsci.2014.03.001

Bhaduri A, Kloos J (2013a) Getting the water prices right using an incentive-based approach: an application of a choice experiment in Khorezm, Uzbekistan. Eur J Dev 25(5):680-694. doi:10.1057/ejdr. 2013.30

Bobojonov I, Aw-Hassan A (2014) Impacts of climate change on farm income security in Central Asia: an integrated modeling approach. Agric Ecosyst Environ 188:245-255. doi:10.1016/j.agee.2014.02. 033

Bobojonov I, Lamers JPA, Bekchanov M, Djanibekov N, Franz-Vasdekid J, Ruzimov J, Martius C (2013a) Options and constraints for crop diversification: a case study in sustainable agriculture. Agroecol Sustain Food Syst 37(7):788-811. doi:10.1080/21683565.2013. 775539

Bucknall L, Klytchnikova I, Lampietti J, Lundell M, Scatasta M, Thurman M (2003) Irrigation in Central Asia: social economic and environmental considerations. World Bank

Crighton EJ, Barwin L, Small I, Upshur R (2011) What have we learned? A review of the literature on children's health and the environment in the Aral Sea area. Int J Public Health 56(2):125-138. doi:10. 1007/s00038-010-0201-0

Dear C, Shigaeva J, Wolfgramm B (2013) Assessing the state of sustainable land management research in Kyrgyzstan and Tajikistan. Mt Res Dev 33(4):443-452. doi:10.1659/MRD-JOURNAL-D-1300050.1

Dukhovny VA, Stulina G (2001) Strategy of transboundary return flow use in the Aral Sea basin. Desalination 139(1-3):299-304. doi:10. 1016/S0011-9164(01)00323-X

FAO (Food and Agriculture Organization of the United Nations) (2012) FAOSTAT database. http://faostat3.fao.org/browse/Q/QC/E. Accessed 21 Feb 2015

Fischer G, Shah M, van Velthuizen H (2002) Climate change and agricultural vulnerability. Preprints. World Summit on Sustainable Development, Johannesburg, p 160

Franz J, Bobojonov I, Egamberdiev O (2010) Assessing the economic viability of organic cotton production in Uzbekistan: a first look. J Sustain Agric 34(1):99-119. doi:10.1080/10440040903396821

Gintzburger G, Toderich KN, Mardonov BK, Mahmudov MM (2003) Rangeland of the arid and semi-arid zones in Uzbekistan. JOUVE, Paris, France: CIRAD-ICARDA, pp. 426

Groll M, Opp C, Aslanov I (2013) Spatial and temporal distribution of the dust deposition in Central Asia-results from a long term monitoring program. Aeolian Res 9:49-62. doi:10.1016/j.aeolia. 2012.08.002

Hamidov A, Beltrao J, Neves A, Khaydarova V, Khamidov M (2007a) Apocynum lancifolium and Chenopodium album - potential species to remediate saline soils. WSEAS Trans Environ Dev 3(7):123-128

Hamidov A, Beltrao J, Costa C, Khaydarova V, Sharipova S (2007b) Environmentally useful technique-Portulaca oleracea golden purslane as a salt removal species. WSEAS Trans Environ Dev 3(7):117-122

Helming K, Diehl K, Bach H, Dilly O, König B, Kuhlman T, Pérez-Soba M, Sieber S, Tabbush P, Tscherning K, Wascher D, Wiggering H (2011a) Ex ante impact assessment of policies affecting land use, part A: analytical framework. Ecol Soc 16(1):27

Helming K, Diehl K, Kuhlman T, Jansson T, Verburg PH, Bakker M, Perez-Soba M, Jones L, Johannes Verkerk P, Tabbush P, Breton Morris J, Drillet Z, Farrington J, LeMouël P, Zagame P, Stuczynski T, Siebielec G, Sieber S, Wiggering H (2011b) Ex ante impact assessment of policies affecting land use, part B: application of the analytical framework. Ecol Soc 16(1):29

Indoitu R, Orlovsky L, Orlovsky N (2012) Dust storms in Central Asia: spatial and temporal variations. J Arid Environ 85:62-70. doi:10. 1016/j.jaridenv.2012.03.018

Kaneko K, Chiba M, Hashizume M, Kunii O, Sasaki S, Shimoda T, Yamashiro Y, Dauletbaev D, Caypil W, Mazhitova Z (2002) Extremely high prevalence of hypercalciuria in children living in the Aral Sea region. Acta Paediatr 91(10):1116-1120. doi:10. 1080/080352502760311638

Kassam K-A (2009) Viewing change through the prism of indigenous human ecology: findings from the Afghan and Tajik Pamirs. Hum Ecol 37(6):377-390. doi:10.1007/s10745-009-9284-8

Khamraev Sh, Dukhovny VA, Kadyrov A, Sokolov V (2011) Water management of Uzbekistan. Scientific Information Centre of the Interstate Commission for Water Coordination (SIC ICWC) of Central Asia. Tashkent, Uzbekistan

Kienzler KM, Lamers JPA, McDonald A, Mirzabaev A, Ibragimov N, Egamberdiev O, Ruzibaev E, Akramkhanov A (2012) Conservation agriculture in Central Asia - what do we know and where do we go from here? Field Crop Res 132:95-105. doi:10.1016/j.fcr.2011.12. 008

König HJ, Uthes S, Schuler J, Zhen L, Purushothaman S, Suarma U, Sghaier M, Makokha S, Helming K, Sieber S, Chen L, Brouwer F, Morris J, Wiggering H (2013) Regional impact assessment of land use scenarios in developing countries using the FoPIA approach: findings from five case studies. J Environ Manag 127:56-64. doi: 10.1016/j.jenvman.2012.10.021

König HJ, Zhen L, Helming K, Uthes S, Li S, Cao X, Wiggering H (2014a) Assessing the impact of the sloping land conversion programme on rural sustainability in Guyuan, Western China. Land Degrad Dev 25(4):385-396. doi:10.1002/ldr.2164

König HJ, Podhora A, Helming K, Zhen L, Wang C, Wübbeke J, Baumeister T, Du B, Yan H (2014b) Confronting international research topics with stakeholders on multifunctional land use: the case of Inner Mongolia, China. iForest 7:403-413. doi:10.3832/ ifor1172-007

Krysanova V, Dickens C, Timmerman J, Varela-Ortega C, Schlüter M, Roest K, Huntjens P, Jaspers F, Buiteveld H, Moreno E, de Pedraza CJ, Slamova R, Martinkova M, Blanco I, Esteve P, Pringle K, PahlWostl C, Kabat P (2010) Cross-comparison of climate change adaptation strategies across large river basins in Europe, Africa and Asia. Water Resour Manag 24(14):4121-4160. doi:10.1007/ s11269-010-9650-8

Kunii O, Hashizume M, Chiba M, Sasaki S, Shimoda T, Caypil W, Dauletbaev D (2003) Respiratory symptoms and pulmonary function among school-age children in the Aral Sea region. Arch Environ Health 58(11):676-682. doi:10.3200/AEOH.58.11.676682 
Kushiev H, Noble A, Abdullaev I, Toshbekov U (2005) Remediation of abandoned saline soils using Glycyrrhiza glabra: a study from the hungry steppes of Central Asia. Int J Agric Sustain 3(2):102-113. doi:10.1080/14735903.2005.9684748

Lal R (2007) Soil and environmental degradation in Central Asia. In: Lal R, Suleimenov M, Stewart BA, Hansen DO, Doraiswamy P (eds) Climate change and terrestrial carbon sequestration in Central Asia. Taylor and Francis, New York, pp 127-136. doi:10.1201/ 9780203932698.ch10

Libert B, Lipponen A (2012) Challenges and opportunities for transboundary water cooperation in Central Asia: findings from UNECE's regional assessment and project work. Int J Water Resour Dev 28(3):565-576. doi:10.1080/07900627.2012.684527

Lioubimtseva E, Cole R, Adams J, Kapustin G (2005) Impacts of climate and land-cover changes in arid lands of Central Asia. J Arid Environ 62(2):285-308. doi:10.1016/j.jaridenv.2004.11.005

Liu M (2011) Central Asia in the post-cold war world. Annu Rev Anthropol 40:115-131. doi:10.1146/annurev-anthro-081309145906

Martius C, Rudenko I, Lamers JPA, Vlek LG (2012) Cotton, water, salts and soums: economic and ecological restructuring in Khorezm, Uzbekistan. Springer, Center for Development Research (ZEF), University of Bonn. doi:10.1007/978-94-007-1963-7

Morris JB, Tassone V, de Groot R, Camilleri M, Moncada S (2011) A framework for participatory impact assessment: involving stakeholders in European policy making, a case study of land use change in Malta. Ecol Soc 16(1):12

Mueller L, Suleimenov M, Karimov A, Qadir M, Saparov A, Balgabayev N, Helming K, Lischeid D (2014) Land and water resources of Central Asia, their utilisation and ecological status. In: Mueller L, Saparov A, Lischeid G (eds.) Novel measurements and assessment tools for monitoring and management of land and water resources in agricultural landscapes of Central Asia. Environmental Science and Engineering, Springer, Switzerland: pp. 3-59. doi:10.1007/978-3319-01017-5 1

Oberkircher L, Shanafield M, Ismailova B, Saito L (2011a) Ecosystem and social construction: an interdisciplinary case study of the Shurkul Lake landscape in Khorezm, Uzbekistan. Ecol Soc 16(4): 20. doi:10.5751/ES-04511-160420

Olcott M (1996) Central Asia's new states: independence, foreign policy, and regional security. United States Institute of Peace Press, Washington, DC

Paracchini ML, Pacini C, Jones M, Laurence M (2011) An aggregation framework to link indicators associated with multifunctional land use to the stakeholder evaluation of policy options. Ecol Indic 11(1):71-80. doi:10.1016/j.ecolind.2009.04.006

Perez-Soba M, Petit S, Jones L, Bertrand N, Briquel V, Omodei-Zorini L, Contini C, Helming K, Farrington J, Mossello M, Wascher D, Kienast F, Groot R (2008) Land use functions - a multifunctionality approach to assess the impact of land use changes on land use sustainability. Springer, Berlin-Heidelberg, Germany, pp 375-404. doi: 10.1007/978-3-540-78648-1_19

Petrick M, Gramzow A, Oshakbaev D, Wandel J (2014) A policy agenda for agricultural development in Kazakhstan. IAMO Policy Brief No.15, Leibniz Institute of Agricultural Development in Transition Economies, Halle (Saale), Germany

Platonov A, Thenkabail P, Biradar C, Cai X, Gumma M, Dheeravath V, Cohen Y, Alchanatis V, Goldshlager N, Ben-Dor E, Vithanage J, Manthrithilake H, Kendjabaev S, Isaev S (2008a) Water productivity mapping (WPM) using Landsat ETM plus data for the irrigated croplands of the Syrdarya River Basin in Central Asia. Sensor 8(12): 8156-8180. doi:10.3390/s8128156

Purushothaman S, Patil S, Francis I, König HJ, Reidsma P, Hedge S (2013) Participatory impact assessment of agricultural practices using the land use functions framework: case study from India. Int
J Biodivers Sci Ecosyst Serv Manag 9(1):2-12. doi:10.1080/ 21513732.2012.721005

Qadir M, Noble AD, Chartres C (2013) Adapting to climate change by improving water productivity of soils in dry areas. Land Degrad Dev 24(1):12-21. doi:10.1002/ldr.1091

Qushimov B, Ganiev IM, Rustamova I, Haitov B, Islam KR (2007) Land degradation by agricultural activities in Central Asia. In: Lal R, Suleimenov M, Stewart BA, Hansen DO, Doraiswamy P (eds) Climate change and terrestrial carbon sequestration in Central Asia. Taylor and Francis, New York, pp 137-146. doi:10.1201/ 9780203932698.ch10

Rakhmatullaev S, Huneau F, Le Coustumer P, Motelica-Heino M, Bakiev M (2010a) Facts and perspectives of water reservoirs in Central Asia: a special focus on Uzbekistan. Water 2(2):307-320. doi:10. 3390/w2020307

Sugimori Y, Funakawa S, Pachikin KM, Ishida N, Kosaki T (2008) Soil salinity dynamics in irrigated fields and its effects on paddy-based rotation systems in southern Kazakhstan. Land Degrad Dev 19(3): 305-320. doi:10.1002/ldr.843

Suleimenov M (2014) Trends in the agriculture of Central Asia and implications for rangelands and croplands. In: Mueller L, Saparov A, Lischeid G (eds.) Novel measurements and assessment tools for monitoring and management of land and water resources in agricultural landscapes of Central Asia. Environmental Science and Engineering, Springer, Switzerland: pp. 91-105. doi:10.1007/9783-319-01017-5 4

Toderich K, Tsukatani T, Black C, Takabe K, Katayama Y (2002) Adaptations of plants to metal/salt contaminated environments: glandular structures and salt excretion. http://ipec.utulsa.edu/ Conf2002/toderich_katayama.pdf. Accessed 13 Feb 2015

van Dijk A, den Haan R, van den Hoven P, Bos R (1999) Can WARMAP save the Aral Sea. Land Water Int 93(2):6-9. doi:10.1007/978-94009-0005-9_2

Varis O (2014) Resources: curb vast water use in central Asia. Nature 514:27-29. doi:10.1038/514027a

WCED (World Commission on Environment and Development) (1987) Our common future. Oxford University Press, New York, United States

Wilhelmsen J, Flikke G (2011) Chinese-Russian convergence and Central Asia. J Geopolit 16(4):865-901. doi:10.1080/14650045. 2010.505119

World Bank (2006) Sustainable land management: challenges, opportunities and tradeoffs. Washington, DC: United States. https:// openknowledge.worldbank.org/handle/10986/7132. Accessed 13 Feb 2015

World Bank (2010) Water and development: an evaluation of World Bank support, 1997-2007. Washington, DC, United States

World Bank (2013) World development indicators. Washington, DC: United States. http://databank.worldbank.org/data/download/WDI2013-ebook.pdf. Accessed 30 June 2015

Xie G, Zhen L, Zhang C, Deng X, König HJ, Tscherning K, Helming K (2010) Assessing the multifunctionalities of land use in China. J Resour Ecol 1(4):311-318. doi:10.3969/j.issn.1674-764x.2010.04. 003

References of the meta-analysis

Abbink K, Moller LC, O'Hara S (2010) Sources of mistrust: an experimental case study of a Central Asian water conflict. Environ Resour Econ 45(2):283-318. doi:10.1007/s10640-009-9316-2 
Abdullaev I, Mollinga PP (2010) The socio-technical aspects of water management: emerging trends at grass roots level in Uzbekistan. Water 2(1):85-100. doi:10.3390/w2010085

Abdullaev I, De Fraiture C, Giordano M, Yakubov M, Rasulov A (2009a) Agricultural water use and trade in Uzbekistan: situation and potential impacts of market liberalization. Int J Water Resour Dev 25(1): 47-63. doi:10.1080/07900620802517533

Abdullaev I, Kazbekov J, Jumaboev K, Manthritilake H (2009b) Adoption of integrated water resources management principles and its impacts: lessons from Ferghana Valley. Water Int 34(2):230-241. doi:10.1080/02508060902843710

Abdullaev I, Kazbekov J, Manthritilake H, Jumaboev K (2009c) Participatory water management at the main canal: a case from South Ferghana canal in Uzbekistan. Agric Water Manag 96(2): 317-329. doi:10.1016/j.agwat.2008.08.013

Abdullaev I, Kazbekov J, Manthritilake H, Jumaboev K (2010) Water user groups in Central Asia: emerging form of collective action in irrigation water management. Water Resour Manag 24(5):1029 1043. doi:10.1007/s11269-009-9484-4

Aierken Y, Akashi Y, Phan TPN, Halidan Y, Tanaka K, Long B, Nishida H, Long CL, Wu MZ, Kato K (2011) Molecular analysis of the genetic diversity of Chinese hami melon and its relationship to the melon germplasm from Central and South Asia. J Jpn Soc Hortic Sci 80(1):52-65. doi:10.2503/jjshs 1.80 .52

Akhtar F, Tischbein B, Awan UK (2013) Optimizing deficit irrigation scheduling under shallow groundwater conditions in lower reaches of Amu Darya river basin. Water Resour Manag 27(8):3165-3178. doi:10.1007/s11269-013-0341-0

Akramkhanov A, Martius C, Park SJ, Hendrickx JMH (2011) Environmental factors of spatial distribution of soil salinity on flat irrigated terrain. Geoderma 163(1-2):55-62. doi:10.1016/j. geoderma.2011.04.001

Astanakulov KD, Karimov YZ, Fozilov G (2011) Design of a grain cleaning machine for small farms. Agric Mech Asia Afr Lat Am 42(4):37-40

Atamanov A, Van den Berg M (2012a) Heterogeneous effects of international migration and remittances on crop income: evidence from the Kyrgyz Republic. World Dev 40(3):620-630. doi:10.1016/j. worlddev.2011.07.008

Atamanov A, Van Den Berg M (2012b) Rural nonfarm activities in Central Asia: a regional analysis of magnitude, structure, evolution and drivers in the Kyrgyz Republic. Eur-Asia Stud 64(2):349-368. doi:10.1080/09668136.2011.642581

Awan UK, Ibrakhimov M, Tischbein B, Kamalov P, Martius C, Lamers JPA (2011a) Improving irrigation water operation in the lower reaches of the Amu Darya river - current status and suggestions. Irrig Drain 60(5):600-612. doi:10.1002/ird.612

Awan UK, Tischbein B, Conrad C, Martius C, Hafeez M (2011b) Remote sensing and hydrological measurements for irrigation performance assessments in a water user association in the lower Amu Darya river basin. Water Resour Manag 25(10):2467-2485. doi:10.1007/ s11269-011-9821-2

Awan UK, Tischbein B, Martius C (2013) Combining hydrological modeling and GIS approaches to determine the spatial distribution of groundwater recharge in an arid irrigation scheme. Irrig Sci 31(4): 793-806. doi:10.1007/s00271-012-0362-0

Aydingun A, Yildirim E (2010) Perception of homeland among Crimean Tatars: cases from Kazakhstan, Uzbekistan and Crimea. Bilig 54: 21-46

Bachmann F (2012) Potential and limitations of organic and fair trade cotton for improving livelihoods of smallholders: evidence from Central Asia. Renew Agric Food Syst 27(2):138-147. doi:10. 1017/s1742170511000202

Bai J, Chen X, Li J, Yang L, Fang H (2011) Changes in the area of inland lakes in arid regions of Central Asia during the past 30 years.
Environ Monit Assess 178(1-4):247-256. doi:10.1007/s10661010-1686-y

Bai J, Chen X, Yang L, Fang H (2012) Monitoring variations of inland lakes in the arid region of Central Asia. Front Earth Sci 6(2):147156. doi:10.1007/s11707-012-0316-0

Balapanova E, Nurgabylov M (2012) Effects of innovation processes on increasing the investment attractiveness of Kazakhstan's agriculture. Actual Probl Econ 138:293-300

Barlow MA, Tippett MK (2008) Variability and predictability of Central Asia river flows: antecedent winter precipitation and large-scale teleconnections. J Hydrometeorol 9(6):1334-1349. doi:10.1175/ 2008jhm976.1

Beek TAD, Voss F, Florke M (2011) Modelling the impact of global change on the hydrological system of the Aral Sea basin. Phys Chem Earth 36(13):684-695. doi:10.1016/j.pce.2011.03.004

Beer R, Kaiser F, Schmidt K, Arnmann B, Carraro G, Grisa E, Tinner W (2008) Vegetation history of the walnut forests in Kyrgyzstan (Central Asia): natural or anthropogenic origin? Quat Sci Rev Rev 27(5-6):621-632. doi:10.1016/j.quascirev.2007.11.012

Beiseyeva G, Abuduwali J (2013) Migration and accumulation of heavy metals in disturbed landscapes in developing ore deposits, east Kazakhstan. J Arid Land 5(2):180-187. doi:10.1007/s40333-0130160-4

Bekchanov M, Karimov A, Lamers JPA (2010a) Impact of water availability on land and water productivity: a temporal and spatial analysis of the case study region Khorezm, Uzbekistan. Water 2(3):668684. doi: $10.3390 / \mathrm{w} 2030668$

Bekchanov M, Lamers JPA, Martius C (2010b) Pros and cons of adopting water-wise approaches in the lower reaches of the Amu Darya: a socio-economic view. Water 2(2):200-216. doi:10.3390/w2020200

Bernauer T, Siegfried T (2008) Compliance and performance in international water agreements: the case of the Naryn/Syr Darya Basin. Glob Gov 14(4):479-501

Bernauer T, Siegfried T (2012) Climate change and international water conflict in Central Asia. J Peace Res 49(1):227-239. doi:10.1177/ 0022343311425843

Bezborodov GA, Bezborodov AG, Bezborodov YG (2008) Distribution of carbon dioxide and methane in the of irrigated sierozems. Eurasian Soil Sci 41(1):63-69. doi:10.1134/s1064229308010079

Bezborodov GA, Shadmanov DK, Mirhashimov RT, Yuldashev T, Qureshi AS, Noble AD, Qadir M (2010) Mulching and water quality effects on soil salinity and sodicity dynamics and cotton productivity in Central Asia. Agric Ecosyst Environ 138(1-2):95-102. doi:10. 1016/j.agee.2010.04.005

Bhaduri A, Kloos J (2013b) Getting the water prices right using an incentive-based approach: an application of a choice experiment in Khorezm, Uzbekistan. Eur J Dev Res 25(5):680-694. doi:10.1057/ ejdr.2013.30

Bichsel C (2012) "The drought does not cause fear," irrigation history in Central Asia through James C. Scott's lenses. Rev Etud Comp EstOuest 43(1-2):73-108

Bobojonov I, Lamers JPA, Bekchanov M, Djanibekov N, Franz-Vasdeki J, Ruzimov J, Martius C (2013b) Options and constraints for crop diversification: a case study in sustainable agriculture in Uzbekistan. Agroecol Sustain Food Syst 37(7):788-811. doi:10.1080/21683565. 2013.775539

Bondarenko DA, Peregontsev EA (2012) Results of studying the feeding of Central Asian tortoise (Agrionemys horsfieldii). Zool Zhurnal 91(11):1397-1410

Bondarenko DA, Peregontsev EA, Mukhtar GB (2008) Current state of steppe tortoise (Agrionemys horsfieldii Gray, 1844) populations in landscapes of southern Kazakhstan. Russian J Ecol 39(3):210-214. doi:10.1134/s1067413608030107

Borchardt P, Schickhoff U, Scheitweiler S, Kulikov M (2011) Mountain pastures and grasslands in the SW Tien Shan, Kyrgyzstan — floristic 
patterns, environmental gradients, phytogeography, and grazing impact. J Mt Sci 8(3):363-373. doi:10.1007/s11629-011-2121-8

Borisov SN (2009) Pattern of dragonfly (Odonata) distribution in Central Asia. Zool Zhurnal 88(1):11-17

Bourgault M, Madramootoo CA, Webber HA, Dutilleul P, Stulina G, Horst MG, Smith DL (2013) Legume production and irrigation strategies in the Aral Sea Basin: yield, yield components, water relations and crop development of common bean (Phaseolus vulgaris L.) and mungbean (Vigna radiata (L.) Wilczek). J Agron Crop Sci 199(4):241-252. doi:10.1111/jac.12016

Breustedt G, Bokusheva R, Heidelbach O (2008) Evaluating the potential of index insurance schemes to reduce crop yield risk in an arid region. J Agric Econ 59(2):312-328. doi:10.1111/j.1477-9552. 2007.00152.x

Brite EB, Marston JM (2013) Environmental change, agricultural innovation, and the spread of cotton agriculture in the old world. J Anthropol Archaeol 32(1):39-53. doi:10.1016/j.jaa.2012.08.003

Buhlmann E, Wolfgramm B, Maselli D, Hurni H, Sanginov SR, Liniger HP (2010) Geographic information system-based decision support for soil conservation planning in Tajikistan. J Soil Water Conserv 65(3):151-159. doi:10.2489/jswc.65.3.151

Bull JW, Suttle KB, Singh NJ, Milner-Gulland EJ (2013) Conservation when nothing stands still: moving targets and biodiversity offsets. Front Ecol Environ 11(4):203-210. doi:10.1890/120020

Buras A, Thevs N, Zerbe S, Wilmking M (2013) Productivity and carbon sequestration of Populus euphratica at the Amu River, Turkmenistan. Forestry 86(4):429-439. doi:10.1093/forestry/ cpt014

Cai XL, Thenkabail PS, Biradar CM, Platonov A, Gumma M, Dheeravath V, Cohen Y, Goldlshleger N, Ben-Dor E, Alchanatis V, Vithanage J, Markandu A (2009) Water productivity mapping using remote sensing data of various resolutions to support "more crop per drop". J Appl Remote Sens 3:23. doi:10.1117/1.3257643

Callaway RM, Schaffner U, Thelen GC, Khamraev A, Juginisov T, Maron JL (2012) Impact of acroptilon repens on co-occurring native plants is greater in the invader's non-native range. Biol Invasions 14(6):1143-1155. doi:10.1007/s10530-011-0145-1

Causarano HJ, Doraiswamy PC, Muratova N, Pachikin K, McCarty GW, Akhmedov B, Williams JR (2011) Improved modeling of soil organic carbon in a semiarid region of Central East Kazakhstan using EPIC. Agron Sustain Dev 31(2):275-286. doi:10.1051/agro/ 2010028

Chen FH, Chen JH, Holmes J, Boomer I, Austin P, Gates JB, Wang NL, Brooks SJ, Zhang JW (2010) Moisture changes over the last millennium in arid Central Asia: a review, synthesis and comparison with monsoon region. Quat Sci Rev Rev 29(7-8):1055-1068. doi:10. 1016/j.quascirev.2010.01.005

Chen X, Li BL, Li Q, Li JL, Abdulla S (2012) Spatio-temporal pattern and changes of evapotranspiration in arid Central Asia and Xinjian of China. J Arid Land 4(1):105-112. doi:10.3724/sp.j.1227.2012. 00105

Chen X, Bai J, Li XY, Luo GP, Li JL, Li BL (2013) Changes in land use/ land cover and ecosystem services in Central Asia during 1990 2009. Curr Opin Environ Sustain 5(1):116-127. doi:10.1016/j. cosust.2012.12.005

Cholpankulov ED, Inchenkova OP, Paredes P, Pereira LS (2008) Cotton irrigation scheduling in Central Asia: model calibration and validation with consideration of groundwater contribution. Irrig Drain 57(5):516-532. doi:10.1002/ird.390

Conrad C, Fritsch S, Zeidler J, Rucker G, Dech S (2010) Per-field irrigated crop classification in arid Central Asia using SPOT and ASTER data. Remote Sens 2(4):1035-1056. doi:10.3390/ rs2041035

Conrad C, Colditz RR, Dech S, Klein D, Vlek PLG (2011) Temporal segmentation of MODIS time series for improving crop classification in Central Asian irrigation systems. Int J Remote Sens 32(23):8763-8778. doi:10.1080/01431161.2010.550647

Conrad C, Dech SW, Hafeez M, Lamers JPA, Tischbein B (2013a) Remote sensing and hydrological measurement based irrigation performance assessments in the upper Amu Darya delta, Central Asia. Phys Chem Earth 61-62:52-62. doi:10.1016/j.pce.2013.05.002

Conrad C, Rahmann M, Machwitz M, Stulina G, Paeth H, Dech S (2013b) Satellite based calculation of spatially distributed crop water requirements for cotton and wheat cultivation in Fergana Valley, Uzbekistan. Glob Planet Change 110:88-98. doi:10.1016/j. gloplacha.2013.08.002

Daribaeva A, Shulenbaeva F, Zholmukhanova A (2012) Actual problems of insurance in agriculture of Kazakhstan. Actual Probl Econ 135(9):284-291

Davis S, Trapman P, Leirs H, Begon M, Heesterbeek JAP (2008) The abundance threshold for plague as a critical percolation phenomenon. Nature 454(7204):634-637. doi:10.1038/nature07053

de Beurs KM, Wright CK, Henebry GM (2009) Dual scale trend analysis for evaluating climatic and anthropogenic effects on the vegetated land surface in Russia and Kazakhstan. Environ Res Lett 4(4):11. doi:10.1088/1748-9326/4/4/045012

de la Martiniere R (2012) Rural livelihood trajectories around a "bull market" in Kyrgyzstan studying agropastoral change at the household level through farming system modeling. Mt Res Dev 32(3): 337-344. doi:10.1659/mrd-journal-d-11-00098.1

Destouni G, Asokan SM, Jarsjo J (2010) Inland hydro-climatic interaction: effects of human water use on regional climate. Geophys Res Lett 37:6. doi:10.1029/2010g1044153

Devkota KP, Manschadi A, Lamers JPA, Devkota M, Vlek PLG (2013a) Mineral nitrogen dynamics in irrigated rice-wheat system under different irrigation and establishment methods and residue levels in arid drylands of Central Asia. Eur J Agron 47:65-76. doi:10.1016/j.eja. 2013.01.009

Devkota KP, Manschadi AM, Devkota M, Lamers JPA, Ruzibaev E, Egamberdiev O, Amiri E, Vlek PLG (2013b) Simulating the impact of climate change on rice phenology and grain yield in irrigated drylands of Central Asia. J Appl Meteorol Climatol 52(9):20332050. doi:10.1175/jamc-d-12-0182.1

Devkota KP, Manschadi AM, Lamers JPA, Humphreys E, Devkota M, Egamberdiev O, Gupta RK, Sayre KD, Vlek PLG (2013c) Growth and yield of rice (Oryza sativa L.) under resource conservation technologies in the irrigated drylands of Central Asia. Field Crops Res 149:115-126. doi:10.1016/j.fcr.2013.04.015

Devkota M, Martius C, Lamers JPA, Sayre KD, Devkota KP, Gupta RK, Egamberdiev O, Vlek PLG (2013d) Combining permanent beds and residue retention with nitrogen fertilization improves crop yields and water productivity in irrigated arid lands under cotton, wheat and maize. Field Crops Res 149:105-114. doi:10.1016/j.fcr.2013.04.012

Devkota M, Martius C, Lamers JPA, Sayre KD, Devkota KP, Vlek PLG (2013e) Tillage and nitrogen fertilization effects on yield and nitrogen use efficiency of irrigated cotton. Soil Tillage Res 134:72-82. doi:10.1016/j.still.2013.07.009

Djanibekov N, van Assche K, Bobojonov I, Lamers JPA (2012a) Farm restructuring and land consolidation in Uzbekistan: new farms with old barriers. Eur-Asia Stud 64(6):1101-1126. doi:10.1080/ 09668136.2012 .691720

Djanibekov U, Khamzina A, Djanibekov N, Lamers JPA (2012b) How attractive are short-term CDM forestations in arid regions? The case of irrigated croplands in Uzbekistan. Forest Policy Econ 21:108117. doi:10.1016/j.forpol.2012.01.006

Djanibekov N, Frohberg K, Djanibekov U (2013a) Income-based projections of water footprint of food consumption in Uzbekistan. Glob Planet Chang 110:130-142. doi:10.1016/j.gloplacha.2013.08.015

Djanibekov N, Sommer R, Djanibekov U (2013b) Evaluation of effects of cotton policy changes on land and water use in Uzbekistan: 
application of a bio-economic farm model at the level of a water users association. Agric Syst 118:1-13. doi:10.1016/j.agsy.2013.02. 004

Djanibekov U, Djanibekov N, Khamzina A, Bhaduri A, Lamers JPA, Berg E (2013c) Impacts of innovative forestry land use on rural livelihood in a bimodal agricultural system in irrigated drylands. Land Use Policy 35:95-106. doi:10.1016/j.landusepol.2013.05.003

Djanibekov U, Van Assche K, Boezeman D, Djanibekov N (2013d) Understanding contracts in evolving agro-economies: fermers, dekhqans and networks in Khorezm, Uzbekistan. J Rural Stud 32: 137-147. doi:10.1016/j.jrurstud.2013.05.003

Djumaeva D, Lamers JPA, Martius C, Vlek PLG (2012) Chlorophyll meters for monitoring foliar nitrogen in three tree species from arid Central Asia. J Arid Environ 85:41-45. doi:10.1016/j.jaridenv.2012. 03.008

Djumaniyazova Y, Sommer R, Ibragimov N, Ruzimov J, Lamers J, Vlek $P(2010)$ Simulating water use and $N$ response of winter wheat in the irrigated floodplains of northwest Uzbekistan. Field Crops Res 116(3):239-251. doi:10.1016/j.fcr.2010.01.001

Doytch N, Eren M (2012) Institutional determinants of sectoral FDI in eastern European and Central Asian countries: the role of investment climate and democracy. Emerg Mark Finance Trade 48:14-32. doi: 10.2753/ree1540-496x4806s402

Dubovyk O, Menz G, Conrad C, Kan E, Machwitz M, Khamzina A (2013a) Spatio-temporal analyses of cropland degradation in the irrigated lowlands of Uzbekistan using remote-sensing and logistic regression modeling. Environ Monit Assess 185(6):4775-4790. doi: 10.1007/s10661-012-2904-6

Dubovyk O, Menz G, Conrad C, Lamers JPA, Lee A, Khamzina A (2013b) Spatial targeting of land rehabilitation: a relational analysis of cropland productivity decline in arid Uzbekistan. Erdkunde 67(2): 167-181. doi:10.3112/erdkunde.2013.02.05

Dubovyk O, Menz G, Conrad C, Thonfeld F, Khamzina A (2013c) Object-based identification of vegetation cover decline in irrigated agro-ecosystems in Uzbekistan. Quat Int 311:163-174. doi:10.1016/ j.quaint.2013.07.043

Dukhovny VA, Sokolov VI, Ziganshina DR (2013) Integrated water resources management in Central Asia, as a way of survival in conditions of water scarcity. Quat Int 311:181-188. doi:10.1016/j.quaint. 2013.07.003

Dybas CL (2008) Newest UNESCO World Heritage site vast wetland complex in land-locked Kazakhstan protects world's most northerly pink flamingoes. Oceanography 21(4):12-13

Earhart K, Vafakolov S, Yarmohamedova N, Michael A, Tjaden J, Soliman A (2009) Risk factors for brucellosis in Samarqand Oblast, Uzbekistan. Int J Infect Dis 13(6):749-753. doi:10.1016/j. ijid.2009.02.014

Edlinger J, Conrad C, Lamers JPA, Khasankhanova G, Koellner T (2012) Reconstructing the spatio-temporal development of irrigation systems in Uzbekistan using Landsat time series. Remote Sens 4(12): 3972-3994. doi:10.3390/rs4123972

Efremova TT, Arbuzova VS, Leonova IN, Makhmudova K (2011) Multiple allelism in the Vrn-B1 locus of common wheat. Cereal Res Commun 39(1):12-21. doi:10.1556/crc.39.2011.1.2

Egamberdieva D, Kucharova Z (2008) Cropping effects on microbial population and nitrogenase activity in saline arid soil. Turk J Biol 32(2):85-90

Egamberdieva D, Renella G, Wirth S, Islam R (2010) Secondary salinity effects on soil microbial biomass. Biol Fertil Soils 46(5):445-449. doi:10.1007/s00374-010-0452-1

Eichholz M, Van Assche K, Oberkircher L, Hornidge AK (2013) Trading capitals? Bourdieu, land and water in rural Uzbekistan. J Environ Plan Manag 56(6):868-892. doi:10.1080/09640568.2012.708650

Eisfelder C, Kuenzer C, Dech S, Buchroithner MF (2013) Comparison of two remote sensing based models for regional net primary productivity estimation - a case study in semi-arid Central Kazakhstan.
IEEE J Sel Top Appl Earth Observ Remote Sens 6(4):1843-1856. doi:10.1109/jstars.2012.2226707

Ewald J, Maart SC, Musshoff O (2012) Measuring the subjective risk attitude of decision-makers: are there differences between groups of methods and of persons? Ger J Agric Econ 61(3):148-161

Eyeberenov S, Cao BJ, Li FT (2009) Problems of Syrdarya river basin management. Front Environ Sci Eng China 3(2):221-225. doi:10. 1007/s11783-009-0015-6

Faye B, Konuspayeva G (2012) The sustainability challenge to the dairy sector-the growing importance of non-cattle milk production worldwide. Int Dairy J 24(2):50-56. doi:10.1016/j.idairyj.2011.12. 011

Faye B, Konuspayeva G, Messad S, Loiseau G (2008) Discriminant milk components of Bactrian camel (Camelus bactrianus), dromedary (Camelus dromedarius) and hybrids. Dairy Sci Technol 88(6):607617. doi:10.1051/dst:2008008

Feilhauer H, Schmidtlein S (2009) Mapping continuous fields of forest alpha and beta diversity. Appl Veg Sci 12(4):429-439

Forkutsa I, Sommer R, Shirokova YI, Lamers JPA, Kienzler K, Tischbein B, Martius C, Vlek PLG (2009a) Modeling irrigated cotton with shallow groundwater in the Aral Sea basin of Uzbekistan: I. Water dynamics. Irrig Sci 27(4):331-346. doi:10.1007/s00271-009-0148-

Forkutsa I, Sommer R, Shirokova YI, Lamers JPA, Kienzler K, Tischbein B, Martius C, Vlek PLG (2009b) Modeling irrigated cotton with shallow groundwater in the Aral Sea basin of Uzbekistan: II. Soil salinity dynamics. Irrig Sci 27(4):319-330. doi:10.1007/s00271009-0149-0

Forster H, Pachova NI, Renaud FG (2011) Energy and land use in the Pamir-Alai Mountains examples from five social-ecological regions. Mt Res Dev 31(4):305-314. doi:10.1659/mrd-journal-d-11-00041.1

Fritsch S, Machwitz M, Ehammer A, Conrad C, Dech S (2012) Validation of the collection 5 MODIS FPAR product in a heterogeneous agricultural landscape in arid Uzbekistan using multitemporal rapideye imagery. Int J Remote Sens 33(21):6818-6837. doi:10.1080/ 01431161.2012 .692834

Gafurov A, Kriegel D, Vorogushyn S, Merz B (2013) Evaluation of remotely sensed snow cover product in Central Asia. Hydrol Res 44(3):506-522. doi:10.2166/nh.2012.094

Gaiser T, Printz A, von Raumer HGS, Gotzinger J, Dukhovny VA, Barthel R, Sorokin A, Tuchin A, Kiourtsidis C, Ganoulis I, Stahr K (2008) Development of a regional model for integrated management of water resources at the basin scale. Phys Chem Earth 33(12):175-182. doi:10.1016/j.pce.2007.04.018

Gessner U, Naeimi V, Klein I, Kuenzer C, Klein D, Dech S (2013) The relationship between precipitation anomalies and satellite-derived vegetation activity in Central Asia. Glob Planet Chang 110:74-87. doi:10.1016/j.gloplacha.2012.09.007

Giraudoux P, Raoul F, Afonso E, Ziadinov I, Yang YR, Li L, Li TY, Quere JP, Feng XH, Wang Q, Wen H, Ito A, Craig PS (2013) Transmission ecosystems of echinococcus multilocularis in China and Central Asia. Parasitology 140(13):1655-1666. doi:10.1017/ s0031182013000644

Giuliani A, van Oudenhoven F, Mubalieva S (2011) Agricultural biodiversity in the Tajik Pamirs: a bridge between market development and food sovereignty. Mt Res Dev 31(1):16-26. doi:10.1659/mrdjournal-d-10-00109.1

Goncalves JM, Muga AP, Horst MG, Pereira LS (2011) Furrow irrigation design with multicriteria analysis. Biosyst Eng 109(4):266-275. doi: 10.1016/j.biosystemseng.2011.04.007

Gracheva I, Karimov A, Turral H, Miryusupov F (2009) An assessment of the potential and impacts of winter water banking in the sokh aquifer, Central Asia. Hydrogeol J 17(6):1471-1482. doi:10.1007/ s10040-009-0444-0

Granit J, Jagerskog A, Lindstrom A, Bjorklund G, Bullock A, Lofgren R, de Gooijer G, Pettigrew S (2012) Regional options for addressing 
the water, energy and food nexus in Central Asia and the Aral Sea basin. Int J Water Resour Dev 28(3):419-432. doi:10.1080/ 07900627.2012 .684307

Gruber FE, Mergili M (2013) Regional-scale analysis of high-mountain multi-hazard and risk indicators in the Pamir (Tajikistan) with grass GIS. Nat Hazards Earth Syst Sci 13(11):2779-2796. doi:10.5194/ nhess-13-2779-2013

Gunchinmaa T, Yakubov M (2010) Institutions and transition: does a better institutional environment make water users associations more effective in Central Asia? Water Policy 12(2):165-185. doi:10.2166/ wp.2009.047

Hbirkou C, Martius C, Khamzina A, Lamers JPA, Welp G, Amelung W (2011) Reducing topsoil salinity and raising carbon stocks through afforestation in Khorezm, Uzbekistan. J Arid Environ 75(2):146155. doi:10.1016/j.jaridenv.2010.09.018

Heaven S, Salter AM, Clarke D, Pak LN (2012) Algal wastewater treatment systems for seasonal climates: application of a simple modelling approach to generate local and regional design guidelines. Water Res 46(7):2307-2323. doi:10.1016/j.watres.2012.01.041

Hegay S, Ortiz R, Garkava-Gustavsson L, Hovmalm HP, Geleta M (2013) Marker-aided breeding for resistance to bean common mosaic virus in Kyrgyz bean cultivars. Euphytica 193(1):67-78. doi:10. 1007/s10681-013-0928-9

Herrfahrdt-Pahle E, Pahl-Wostl C (2012) Continuity and change in socialecological systems: the role of institutional resilience. Ecol Soc 17(2):14. doi:10.5751/es-04565-170208

Heubeck C, Ergaliev G, Evseev S (2013) Large-scale seismogenic deformation of a carbonate platform straddling the PrecambrianCambrian boundary, Karatau range, Kazakhstan. J Sediment Res 83(11-12):1005-1025. doi:10.2110/jsr.2013.76

Hill J (2013) The role of authority in the collective management of hill irrigation systems in the Alai (Kyrgyzstan) and Pamir (Tajikistan). Mt Res Dev 33(3):294-304. doi:10.1659/mrd-journal-d-12-00127.1

Hirsch D, Abrami G, Giordano R, Liersch S, Matin N, Schluter M (2010) Participatory research for adaptive water management in a transition country - a case study from Uzbekistan. Ecol Soc 15(3):33

Hornidge AK, Oberkircher L, Tischbein B, Schorcht G, Bhaduri A, Manschadi AM (2011) Reconceptualizing water management in Khorezm, Uzbekistan. Nat Resour Forum 35(4):251-268. doi:10. 1111/j.1477-8947.2011.01391.x

Hornidge AK, Oberkircher L, Kudryavtseva A (2013) Boundary management and the discursive sphere-negotiating 'realities' in Khorezm, Uzbekistan. Geoforum 45:268-276. doi:10.1016/j. geoforum.2012.11.014

Hunt HV, Campana MG, Lawes MC, Park YJ, Bower MA, Howe CJ, Jones MK (2011) Genetic diversity and phylogeography of broomcorn millet (Panicum miliaceum L.) across Eurasia. Mol Ecol 20(22):4756-4771. doi:10.1111/j.1365-294X.2011.05318.x

Ibragimov N, Evett S, Esenbekov Y, Khasanova F, Karabaev I, Mirzaev L, Lamers J (2011) Permanent beds vs. conventional tillage in irrigated arid Central Asia. Agron J 103(4):1002-1011. doi:10.2134/ agronj 2010.0111

Ibrakhimov M, Martius C, Lamers JPA, Tischbein B (2011) The dynamics of groundwater table and salinity over 17 years in Khorezm. Agric Water Manag 101(1):52-61. doi:10.1016/j.agwat.2011.09. 002

Iniguez L (2011) The challenges of research and development of small ruminant production in dry areas. Small Rumin Res 98(1-3):12-20. doi:10.1016/j.smallrumres.2011.03.010

Ionov M, Yuldasheva N, Ulchenko N, Glushenkova AI, Heuer B (2013) Growth, development and yield of crambe abyssinica under saline irrigation in the greenhouse. J Agron Crop Sci 199(5):331-339. doi: 10.1111 jac. 12027

Jahjah M, Ulivieri C (2010) Automatic archaeological feature extraction from satellite VHR images. Acta Astronaut 66(9-10):1302-1310. doi:10.1016/j.actaastro.2009.10.028
Jalankuzov T, Suleimenov B, Busscher WJ, Stone KC, Bauer PJ (2013) Irrigated cotton grown on sierozem soils in south Kazakhstan. Commun Soil Sci Plant Anal 44(22):3391-3399. doi:10.1080/ 00103624.2013 .847449

Jalilov SM, Amer S, Ward F (2013a) Water, food, and energy security: an elusive search for balance in Central Asia. Water Resour Manag 27(11):3959-3979. doi:10.1007/s11269-013-0390-4

Jalilov SM, Amer SA, Ward FA (2013b) Reducing conflict in development and allocation of transboundary rivers. Eurasian Geogr Econ 54(1):78-109. doi:10.1080/15387216.2013.788873

Jamal SM, Ferrari G, Hussain M, Nawroz AH, Aslami AA, Khan E, Murvatulloev S, Ahmed S, Belsham GJ (2012) Detection and genetic characterization of foot-and-mouth disease viruses in samples from clinically healthy animals in endemic settings. Transbound Emerg Dis 59(5):429-440. doi:10.1111/j.1865-1682.2011.01295.x

Jarsjo J, Asokan SM, Prieto C, Bring A, Destouni G (2012) Hydrological responses to climate change conditioned by historic alterations of land-use and water-use. Hydrol Earth Syst Sci 16(5):1335-1347. doi:10.5194/hess-16-1335-2012

Johansson O, Aimbetov I, Jarsjo J (2009) Variation of groundwater salinity in the partially irrigated Amudarya river delta, Uzbekistan. J Mar Syst 76(3):287-295. doi:10.1016/j.jmarsys.2008.03.017

Jozan R (2012) Hidden production? In quest of the "second crop" in the oases of Uzbekistan. Rev Etud Comp Est-Ouest 43(1-2):109-135

Kabdullina G (2012) Key directions for efficiency increase in agricultural production. Actual Probl Econ 138(12):381-388

Kaganova O, Akmatov A, Undeland C (2008) Introducing more transparent and efficient land management in post-socialist cities: lessons from Kyrgyzstan. Int J Strateg Prop Manag 12(3):161-181. doi:10. 3846/1648-715x.2008.12.161-181

Kamp J, Koshkin MA, Sheldon RD (2009a) Population size, breeding performance and habitat use of the black-winged Pratincole glareola Nordmanni. Bird Conserv Int 19(2):149-163. doi:10.1017/ s0959270908008150

Kamp J, Sheldon RD, Koshkin MA, Donald PF, Biedermann R (2009b) Post-Soviet steppe management causes pronounced synanthropy in the globally threatened Sociable Lapwing Vanellus gregarius. Ibis 151(3):452-463. doi:10.1111/j.1474-919X.2009.00938.x

Kamp J, Urazaliev R, Donald PF, Holzel N (2011) Post-soviet agricultural change predicts future declines after recent recovery in Eurasian steppe bird populations. Biol Conserv 144(11):2607-2614. doi:10. 1016/j.biocon.2011.07.010

Kamp J, Siderova TV, Salemgareev AR, Urazaliev RS, Donald PF, Holzel N (2012) Niche separation of larks (Alaudidae) and agricultural change on the drylands of the former Soviet Union. Agric Ecosyst Environ 155:41-49. doi:10.1016/j.agee.2012.03.023

Karimov A, Qadir M, Noble A, Vyshpolsky F, Anzelm K (2009) Development of magnesium-dominant soils under irrigated agriculture in southern Kazakhstan. Pedosphere 19(3):331-343. doi:10. 1016/S1002-0160(09)60124-7

Karimov A, Smakhtin V, Mavlonov A, Gracheva I (2010) Water 'banking' in Fergana Valley aquifers - a solution to water allocation in the Syrdarya river basin? Agric Water Manag 97(10):1461-1468. doi: 10.1016/j.agwat.2010.04.011

Karimov A, Giordano M, Mukherji A, Borisov V, Djumanov J (2012a) Of transboundary basins, integrated water resources management (IWRM) and second best solutions: the case of groundwater banking in Central Asia. Water Policy 14(1):99-111. doi:10.2166/wp.2011. 149

Karimov A, Mavlonov A, Miryusupov F, Gracheva I, Borisov V, Abdurahmonov B (2012b) Modelling policy alternatives toward managed aquifer recharge in the Fergana Valley, Central Asia. Water Int 37(4):380-394. doi:10.1080/02508060.2012.706432

Karimov A, Molden D, Khamzina T, Platonov A, Ivanov Y (2012c) A water accounting procedure to determine the water savings potential 
of the Fergana Valley. Agric Water Manag 108:61-72. doi:10.1016/ j.agwat.2011.11.010

Karimov KS, Akhmedov KM, Abid M, Petrov GN (2013) Effective management of combined renewable energy resources in Tajikistan. Sci Total Environ 461:835-838. doi:10.1016/j.scitotenv. 2013.05.095

Kariyeva J, van Leeuwen WJD (2011) Environmental drivers of NDVIbased vegetation phenology in Central Asia. Remote Sens 3(2):203246. doi:10.3390/rs3020203

Kariyeva J, van Leeuwen WJD (2012) Phenological dynamics of irrigated and natural drylands in Central Asia before and after the ussr collapse. Agric Ecosyst Environ 162:77-89. doi:10.1016/j.agee. 2012.08.006

Kariyeva J, van Leeuwen WJD, Woodhouse CA (2012) Impacts of climate gradients on the vegetation phenology of major land use types in Central Asia (1981-2008). Front Earth Sci 6(2):206-225. doi:10. 1007/s11707-012-0315-1

Karnieli A, Gilad U, Ponzet M, Svoray T, Mirzadinov R, Fedorina O (2008) Assessing land-cover change and degradation in the Central Asian deserts using satellite image processing and geostatistical methods. J Arid Environ 72(11):2093-2105. doi:10. 1016/j.jaridenv.2008.07.009

Kassam A, Friedrich T, Derpsch R, Lahmar R, Mrabet R, Basch G, Gonzalez-Sanchez EJ, Serraj R (2012) Conservation agriculture in the dry Mediterranean climate. Field Crops Res 132:7-17. doi:10. 1016/j.fcr.2012.02.023

Katsenovich Y, Shapovalova L, But L, Ijitskaja M (2008) Evaluation of biological pond system modified with submerged planted dams. Ecol Eng 33(1):1-7. doi:10.1016/j.ecoleng.2007.09.008

Kawabata V, Aparin V, Nagai M, Yamainoto M, Shiraishi K, Katayama Y (2008) Uranium and thorium isotopes from Kazakhstan. J Radioanal Nucl Chem 278(2):459-462. doi:10.1007/s10967-008-0904-3

Kazbekov J, Abdullaev I, Manthrithilake H, Qureshi A, Jumaboev K (2009) Evaluating planning and delivery performance of water user associations (WUAs) in Osh province, Kyrgyzstan. Agric Water Manag 96(8):1259-1267. doi:10.1016/j.agwat.2009.04.002

Kerven C, Steimann B, Dear C, Ashley L (2012) Researching the future of pastoralism in Central Asia's mountains: examining development orthodoxies. Mt Res Dev 32(3):368-377. doi:10.1659/mrd-journald-12-00035.1

Khamzina A, Lamers JPA, Vlek PLG (2008) Tree establishment under deficit irrigation on degraded agricultural land in the lower Amu Darya river region, Aral Sea basin. For Ecol Manag 255(1):168178. doi:10.1016/j.foreco.2007.09.005

Khamzina A, Lamers JPA, Vlek PLG (2009a) Nitrogen fixation by Elaeagnus angustifolia in the reclamation of degraded croplands of Central Asia. Tree Physiol 29(6):799-808. doi:10.1093/ treephys/tpp017

Khamzina A, Sommer R, Lamers JPA, Vlek PLG (2009b) Transpiration and early growth of tree plantations established on degraded cropland over shallow saline groundwater table in northwest Uzbekistan. Agric For Meteorol 149(11):1865-1874. doi:10.1016/j.agrformet. 2009.06.015

Kienzler KM, Djanibekov N, Lamers JPA (2011a) An agronomic, economic and behavioral analysis of $\mathrm{N}$ application to cotton and wheat in post-Soviet Uzbekistan. Agric Syst 104(5):411-418. doi:10.1016/ j.agsy.2011.01.005

Kienzler KM, Rudenko I, Ruzimov J, Ibragimov N, Lamers JPA (2011b) Winter wheat quantity or quality? Assessing food security in Uzbekistan. Food Secur 3(1):53-64. doi:10.1007/s12571-0100109-9

Kipping M (2008) Can "integrated water resources management" silence Malthusian concerns? The case of Central Asia. Water Int 33(3): 305-319. doi:10.1080/02508060802279569
Kitamura K (2008) Issues of water users' associations for sustainable irrigation and drainage in Central Asia. Jarq - Jpn Agric Res Q 42(3):203-210

Klein I, Gessner U, Kuenzer C (2012) Regional land cover mapping and change detection in Central Asia using MODIS time-series. Appl Geogr 35(1-2):219-234. doi:10.1016/j.apgeog.2012.06.016

Koch N (2010) The monumental and the miniature: imagining 'modernity' in Astana. Soc Cult Geogr 11(8):769-787. doi:10.1080/ 14649365.2010.521854

Konuspayeva G, Lemarie E, Faye B, Loiseau G, Montet D (2008) Fatty acid and cholesterol composition of camel's (Camelus bactrianus, Camelus dromedarius and hybrids) milk in Kazakhstan. Dairy Sci Technol 88(3):327-340. doi:10.1051/dst:2008005

Konuspayeva G, Faye B, Loiseau G, Narmuratova M, Ivashchenko A, Meldebekova A, Davletov S (2010) Physiological change in camel milk composition (Camelus dromedarius) 2: physico-chemical composition of colostrum. Trop Anim Health Prod 42(3):501-505. doi: 10.1007/s11250-009-9450-4

Kosimov FF, Kosimov MA, Rischkowsky B, Mueller JP (2013) Evaluation of mohair quality in Angora goats from the Northern dry lands of Tajikistan. Small Rumin Res 113(1):73-79. doi:10. 1016/j.smallrumres.2013.02.002

Kotte K, Low F, Huber SG, Krause T, Mulder I, Scholer HF (2012) Organohalogen emissions from saline environments - spatial extrapolation using remote sensing as most promising tool. Biogeosciences 9(3):1225-1235. doi:10.5194/bg-9-1225-2012

Kracalik IT, Blackburn JK, Lukhnova L, Pazilov Y, Hugh-Jones ME, Aikimbayev A (2012) Analysing the spatial patterns of livestock anthrax in Kazakhstan in relation to environmental factors: a comparison of local $\left(\mathrm{G}_{\mathrm{i}}^{*}\right)$ and morphology cluster statistics. Geospatial Health 7(1):111-126

Krysanova V, Buiteveld H, Haase D, Hattermann FF, van Niekerk K, Roest K, Martinez-Santos P, Schluter M (2008) Practices and lessons learned in coping with climatic hazards at the river-basin scale: floods and droughts. Ecol Soc 13(2):20

Lamers JPA, Martius C, Khamzina A, Matkarimova M, Djumaeva D, Eshchanov R (2010) Green foliage decomposition in tree plantations on degraded, irrigated croplands in Uzbekistan, Central Asia. Nutr Cycl Agroecosyst 87(2):249-260. doi:10.1007/s10705-009-9336-x

Larson KM, Small EE, Gutmann E, Bilich A, Axelrad P, Braun J (2008) Using GPS multipath to measure soil moisture fluctuations: initial results. GPS Solut 12(3):173-177. doi:10.1007/s10291-007-0076-6

Lebed L, Qi J, Heilman P (2012) An ecological assessment of pasturelands in the Balkhash area of Kazakhstan with remote sensing and models. Environ Res Lett 7(2):8. doi:10.1088/1748-9326/7/2/ 025203

Lerman Z (2008) Agricultural development in Central Asia: a survey of Uzbekistan, 2007-2008. Eurasian Geogr Econ 49(4):481-505. doi: 10.2747/1539-7216.49.4.481

Lerman Z, Sedik D (2009) Agricultural development and household incomes in Central Asia: a survey of Tajikistan, 2003-2008. Eurasian Geogr Econ 50(3):301-326. doi:10.2747/1539-7216.50.3.301

Liechti K (2012) The meanings of pasture in resource degradation negotiations: evidence from post-socialist rural Kyrgyzstan. Mt Res Dev 32(3):304-312. doi:10.1659/mrd-journal-d-11-00113.1

Lin HW, Jin YF, Giglio L, Foley JA, Randerson JT (2012) Evaluating greenhouse gas emissions inventories for agricultural burning using satellite observations of active fires. Ecol Appl 22(4):1345-1364. doi:10.1890/10-2362.1

Lioubimtseva E, Henebry GM (2009) Climate and environmental change in arid Central Asia: impacts, vulnerability, and adaptations. J Arid Environ 73(11):963-977. doi:10.1016/j.jaridenv.2009.04.022

Lioubimtseva E, Henebry GM (2012) Grain production trends in Russia, Ukraine and Kazakhstan: new opportunities in an increasingly unstable world? Front Earth Sci 6(2):157-166. doi:10.1007/s11707012-0318-y 
Litvinchuk SN, Mazepa GO, Pasynkova RA, Saidov A, Satorov T, Chikin YA, Shabanov DA, Crottini A, Borkin LJ, Rosanov JM, Stock M (2011) Influence of environmental conditions on the distribution of Central Asian green toads with three ploidy levels. J Zool Syst Evol Res 49(3):233-239. doi:10.1111/j.1439-0469.2010. 00612.x

Loboda TV, Giglio L, Boschetti L, Justice CO (2012) Regional fire monitoring and characterization using global NASA MODIS fire products in dry lands of Central Asia. Front Earth Sci 6(2):196-205. doi: 10.1007/s11707-012-0313-3

Low F, Michel U, Dech S, Conrad C (2013a) Impact of feature selection on the accuracy and spatial uncertainty of per-field crop classification using Support Vector Machines. ISPRS-J Photogramm Remote Sens 85:102-119. doi:10.1016/j.isprsjprs.2013.08.007

Low F, Navratil P, Kotte K, Scholer HF, Bubenzer O (2013b) Remotesensing-based analysis of landscape change in the desiccated seabed of the Aral Sea - a potential tool for assessing the hazard degree of dust and salt storms. Environ Monit Assess 185(10):8303-8319. doi:10.1007/s10661-013-3174-7

Magalon H, Patin E, Austerlitz F, Hegay T, Aldashev A, Quintana-Murci L, Heyer E (2008) Population genetic diversity of the nat2 gene supports a role of acetylation in human adaptation to farming in Central Asia. Eur J Hum Genet 16(2):243-251. doi:10.1038/sj. ejhg. 5201963

Malakhov DV, Dyke GJ, King C (2009) Remote sensing applied to paleontology: exploration of Upper Cretaceous sediments in Kazakhstan for potential fossil sites. Palaeontol Electron 12(2):10

Malatesta LC, Castelltort S, Mantellini S, Picotti V, Hajdas I, Simpson G, Berdimuradov AE, Tosi M, Willett SD (2012) Dating the irrigation system of the Samarkand oasis: a geoarchaeological study. Radiocarbon 54(1):91-105. doi:10.2458/azu js rc.v54i1.15839

Maman S, Orlovsky L, Blumberg DG, Berliner P, Mamedov B (2011) A landcover change study of takyr surfaces in Turkmenistan. J Arid Environ 75(9):842-850. doi:10.1016/j.jaridenv.2011.04.002

Mamilov A, Dilly O (2011) Shifts in respiratory quotient and delta C-13 isotopic signature of $\mathrm{CO} 2$ produced by soils under long-term agricultural use in arid steppe ecosystems. Geomicrobiol J 28(7):625631. doi:10.1080/01490451.2011.581015

Mariotto I, Thenkabail PS, Huete A, Slonecker ET, Platonov A (2013) Hyperspectral versus multispectral crop-productivity modeling and type discrimination for the HyspIRI mission. Remote Sens Environ 139:291-305. doi:10.1016/j.rse.2013.08.002

Markofsky S, Bevan A (2012) Directional analysis of surface artefact distributions: a case study from the Murghab Delta, Turkmenistan. J Archaeol Sci 39(2):428-439. doi:10.1016/j.jas.2011.09.031

Martinez-Cruz B, Vitalis R, Segurel L, Austerlitz F, Georges M, Thery S, Quintana-Murci L, Hegay T, Aldashev A, Nasyrova F, Heyer E (2011) In the heartland of Eurasia: the multilocus genetic landscape of Central Asian populations. Eur J Hum Genet 19(2):216-223. doi: 10.1038/ejhg.2010.153

Massacci A, Nabiev SM, Pietrosanti L, Nematov SK, Chernikova TN, Thor K, Leipner J (2008) Response of the photosynthetic apparatus of cotton (Gossypium hirsutum) to the onset of drought stress under field conditions studied by gas-exchange analysis and chlorophyll fluorescence imaging. Plant Physiol Biochem 46(2):189-195. doi: 10.1016/j.plaphy.2007.10.006

Matsuyama H, Kezer K (2009) Long-term variation of precipitation around Lake Balkhash in Central Asia from the end of the 19th century. Sola 5:73-76. doi:10.2151/sola.2009-019

Matthys B, Sherkanov T, Karimov SS, Khabirov Z, Mostowlansky T, Utzinger J, Wyss K (2008) History of malaria control in Tajikistan and rapid malaria appraisal in an agro-ecological setting. Malar J 7: 11. doi:10.1186/1475-2875-7-217

Matthys B, Bobieva M, Karimova G, Mengliboeva Z, Jean-Richard V, Hoimnazarova M, Kurbonova M, Lohourignon LK, Utzinger J, Wyss K (2011) Prevalence and risk factors of helminths and intestinal protozoa infections among children from primary schools in western Tajikistan. Parasit Vectors 4:13. doi:10.1186/1756-33054-195

McGregor BA, Kerven C, Toigonbaev S (2009) Sources of variation contributing to production and quality attributes of Kyrgyz cashmere in Osh and Naryn provinces: implications for industry development. Small Rumin Res 84(1-3):89-99. doi:10.1016/j.smallrumres.2009. 06.008

McGregor BA, Kerven C, Toigonbaev S (2011) Sources of variation affecting cashmere grown in the Pamir mountain districts of Tajikistan and implications for industry development. Small Rumin Res 99(1):7-15. doi:10.1016/j.smallrumres.2011.01.018

Mergili M, Schneider JF (2011) Regional-scale analysis of lake outburst hazards in the southwestern Pamir, Tajikistan, based on remote sensing and GIS. Nat Hazards Earth Syst Sci 11(5):1447-1462. doi:10. 5194/nhess-11-1447-2011

Mergili M, Muller JP, Schneider JF (2013) Spatio-temporal development of high-mountain lakes in the headwaters of the Amu Darya River (Central Asia). Glob Planet Chang 107:13-24. doi:10.1016/j. gloplacha.2013.04.001

Mislimshoeva B, Samimi C, Kirchhoff JF, Koellner T (2013) Analysis of costs and people's willingness to enroll in forest rehabilitation in Gorno Badakhshan, Tajikistan. Forest Policy Econ 37:75-83. doi: 10.1016/j.forpol.2012.12.001

Molinar RH (2012) Evaluation of Central Asian melon varieties in the San Joaquin Valley. J Am Pomol Soc 66(3):122-124

Mollinga PP (2010) Boundary work and the complexity of natural resources management. Crop Sci 50(2):S1-S9. doi:10.2135/ cropsci2009.10.0570

Mosaad M, Morgounov A, Gomez H, Jarrah M, Rajaram S (2008) Variation in agronomic, rust reaction and grain quality characteristics in a collection of winter and facultative wheat varieties. Cereal Res Commun 36(3):441-450. doi:10.1556/crc.36.2008.3.8

Motagh M, Wetzel HU, Roessner S, Kaufmann H (2013) A TerraSAR-X InSAR study of landslides in southern Kyrgyzstan, Central Asia. Remote Sens Lett 4(7):657-666. doi:10.1080/2150704x.2013. 782111

Mullins JC, Garofolo G, Van Ert M, Fasanella A, Lukhnova L, HughJones ME, Blackburn JK (2013) Ecological niche modeling of Bacillus anthracis on three continents: evidence for geneticecological divergence? PLoS One 8(8):8. doi:10.1371/journal. pone. 0072451

Naeem R, Dahleen L, Mirza B (2011) Genetic differentiation and geographical relationship of Asian barley landraces using SSRs. Genet Mol Biol 34(2):268-273. doi:10.1590/S1415-47572011005000014

Narama C, Duishonakunov M, Kaab A, Daiyrov M, Abdrakhmatov K (2010a) The 24 july 2008 outburst flood at the western Zyndan glacier lake and recent regional changes in glacier lakes of the Teskey Ala-Too range, Tien Shan, Kyrgyzstan. Nat Hazards Earth Syst Sci 10(4):647-659. doi:10.5194/nhess-10-647-2010

Narama C, Kaab A, Duishonakunov M, Abdrakhmatov K (2010b) Spatial variability of recent glacier area changes in the Tien Shan Mountains, Central Asia, using Corona (similar to 1970), Landsat (similar to 2000), and ALOS (similar to 2007) satellite data. Glob Planet Chang 71(1-2):42-54. doi:10.1016/j.gloplacha.2009.08.002

Navratil P, Wilps H (2013) Object-based locust habitat mapping using high-resolution multispectral satellite data in the southern Aral Sea basin. J Appl Remote Sens 7:21. doi:10.1117/1.jrs.7.075097

Newcomb M, Acevedo M, Bockelman HE, Brown-Guedira G, Goates BJ, Jackson EW, Jin Y, Njau P, Rouse MN, Singh D, Wanyera R, Bonman JM (2013) Field resistance to the Ug99 race group of the stem rust pathogen in spring wheat landraces. Plant Dis 97(7):882890. doi:10.1094/pdis-02-12-0200-re

Niederer P, Bilenko V, Ershova N, Hurni H, Yerokhin S, Maselli D (2008) Tracing glacier wastage in the northern Tien Shan (Kyrgyzstan/ 
Central Asia) over the last 40 years. Clim Chang 86(1-2):227-234. doi:10.1007/s10584-007-9288-6

Nurzhanovna AG (2011) Cotton and textile branch of Kazakhstan State: problems and prospects for the development. Afr J Agric Res 6(17): 4034-4045. doi:10.5897/AJAR11.207

Nurzhanovna AG (2012) World practice and development history of cotton-growing in Kazakhstan. Actual Probl Econ 127(8):342-351

Oberhansli H, Weise SM, Stanichny S (2009) Oxygen and hydrogen isotopic water characteristics of the Aral Sea, Central Asia. J Mar Syst 76(3):310-321. doi:10.1016/j.jmarsys.2008.03.019

Oberhansli H, Novotna K, Piskova A, Chabrillat S, Nourgaliev DK, Kurbaniyazov AK, Matys Grygar T (2011) Variability in precipitation, temperature and river runoff in $\mathrm{W}$ Central Asia during the past similar to 2000 yrs. Glob Planet Chang 76(1-2):95-104. doi:10. 1016/j.gloplacha.2010.12.008

Oberkircher L (2011) On pumps and paradigms: water scarcity and technology adoption in Uzbekistan. Soc Nat Resour 24(12):1270-1285. doi:10.1080/08941920.2010.550085

Oberkircher L, Hornidge AK (2011) "Water is life"_farmer rationales and water saving in Khorezm, Uzbekistan: a lifeworld analysis. Rural Sociol 76(3):394-421. doi:10.1111/j.1549-0831.2011.00054. $\mathrm{x}$

Oberkircher L, Shanafield M, Ismailova B, Saito L (2011b) Ecosystem and social construction: an interdisciplinary case study of the Shurkul Lake landscape in Khorezm, Uzbekistan. Ecol Soc 16(4): 10. doi:10.5751/es-04511-160420

Obertreis J (2008) The "attack on the desert" in Central Asia - on the environmental history of the Soviet Union. Osteuropas 58(4-5):37

Olsson O, Gassmann M, Wegerich K, Bauer M (2010) Identification of the effective water availability from streamflows in the Zerafshan river basin, Central Asia. J Hydrol 390(3-4):190-197. doi:10.1016/ j.jhydrol.2010.06.042

Olsson O, Gassmann M, Manig N, Ikramova M, Wegerich K (2013) Basin efficiency approach and its effect on streamflow quality, Zerafshan River Uzbekistan. J Hydrol 476:128-135. doi:10.1016/j. jhydrol.2012.10.022

Osmonov A, Bolch T, Xi C, Kurban A, Guo WQ (2013) Glacier characteristics and changes in the Sary-Jaz River Basin (Central Tien Shan, Kyrgyzstan)-1990-2010. Remote Sens Lett 4(8):725-734. doi:10. 1080/2150704x.2013.789146

Outram AK, Stear NA, Kasparov A, Usmanova E, Varfolomeev V, Evershed RP (2011) Horses for the dead: funerary foodways in Bronze Age Kazakhstan. Antiquity 85(327):116-128

Ozturk T, Altinsoy H, Turkes M, Kurnaz ML (2012) Simulation of temperature and precipitation climatology for the Central Asia CORDEX domain using RegCM 4.0. Clim Res 52(1):63-76. doi: $10.3354 / \mathrm{cr} 01082$

Pankova EI, Konyushkova MV (2013) Climate and soil salinity in the deserts of Central Asia. Eurasian Soil Sci 46(7):721-727. doi:10. 1134/s1064229313070065

Passmore DG, Harrison S, Winchester V, Rae A, Severskiy I, Pimankina NV (2008) Late Holocene debris flows and valley floor development in the northern Zailiiskiy Alatau, Tien Shan Mountains, Kazakhstan. Arct Antarct Alp Res 40(3):548-560. doi:10.1657/ 1523-0430(06-078)[passmore]2.0.co;2

Pen-Mouratov S, Shukurov N, Steinberger Y (2010) Soil free-living nematodes as indicators of both industrial pollution and livestock activity in Central Asia. Ecol Indic 10(5):955-967. doi:10.1016/j.ecolind. 2010.02.005

Pereira LS, Paredes P, Cholpankulov ED, Inchenkova OP, Teodoro PR, Horst MG (2009) Irrigation scheduling strategies for cotton to cope with water scarcity in the Fergana Valley, Central Asia. Agric Water Manag 96(5):723-735. doi:10.1016/j.agwat.2008.10.013

Pereira-Cardenal SJ, Riegels ND, Berry PAM, Smith RG, Yakovlev A, Siegfried TU, Bauer-Gottwein P (2011) Real-time remote sensing driven river basin modeling using radar altimetry. Hydrol Earth Syst Sci 15(1):241-254. doi:10.5194/hess-15-241-2011

Perez-Quezada JF, Saliendra NZ, Akshalov K, Johnson DA, Laca EA (2010) Land use influences carbon fluxes in northern Kazakhstan. Rangeland Ecol Manag 63(1):82-93. doi:10.2111/08-106.1

Petrick M, Wandel J, Karsten K (2013) Rediscovering the virgin lands: agricultural investment and rural livelihoods in a Eurasian frontier area. World Dev 43:164-179. doi:10.1016/j.worlddev.2012.09.015

Petrov GN, Normatov IS (2010) Conflict of interests between water users in the Central Asian region and possible ways to its elimination. Water Resour 37(1):113-120. doi:10.1134/s0097807810010112

Platonov A, Thenkabail PS, Biradar CM, Cai XL, Gumma M, Dheeravath V, Cohen Y, Alchanatis V, Goldshlager N, Ben-Dor E, Vithanage J, Manthrithilake H, Kendjabaev S, Isaev S (2008b) Water productivity mapping (WPM) using Landsat ETM+ data for the irrigated croplands of the Syrdarya River Basin in Central Asia. Sensors 8(12):8156-8180. doi:10.3390/s8128156

Propastin P (2012) Multisensor monitoring system for assessment of locust hazard risk in the Lake Balkhash drainage basin. Environ Manag 50(6):1234-1246. doi:10.1007/s00267-012-9950-2

Propastin P, Kappas M (2009a) Modeling net ecosystem exchange for grassland in Central Kazakhstan by combining remote sensing and field data. Remote Sens 1(3):159-183. doi:10.3390/rs1030159

Propastin PA, Kappas M (2009b) Integration of Landsat ETM+ data with field measurements for mapping Leaf Area Index in the grasslands of Central Kazakhstan. GISci Remote Sens 46(2):212-231. doi:10. 2747/1548-1603.46.2.212

Propastin P, Kappas M (2012) Retrieval of coarse-resolution leaf area index over the Republic of Kazakhstan using NOAA AVHRR satellite data and ground measurements. Remote Sens 4(1):220-246. doi: $10.3390 /$ rs 4010220

Propastin PA, Kappas M, Muratova NR (2008) Inter-annual changes in vegetation activities and their relationship to temperature and precipitation in Central Asia from 1982 to 2003. J Environ Inf 12(2): 75-87. doi:10.3808/jei.200800126

Qadir M, Noble AD, Qureshi AS, Gupta RK, Yuldashev T, Karimov A (2009) Salt-induced land and water degradation in the Aral Sea Basin: a challenge to sustainable agriculture in Central Asia. Nat Resour Forum 33(2):134-149. doi:10.1111/j.1477-8947.2009. 01217.x

Qi JG, Bobushev TS, Kulmatov R, Groisman P, Gutman G (2012) Addressing global change challenges for Central Asian socio-ecosystems. Front Earth Sci 6(2):115-121. doi:10.1007/s11707-0120320-4

Qureshi AS, Eshmuratov D, Bezborodov G (2011) Determining optimal groundwater table depth for maximizing cotton production in the Sardarya province of Uzbekistan. Irrig Drain 60(2):241-252. doi: 10.1002/ird.568

Rakhmatullaev S, Huneau F, Kazbekov J, Le Coustumer P, Jumanov J, El Oifi B, Motelica-Heino M, Hrkal Z (2010b) Groundwater resources use and management in the Amu Darya River Basin (Central Asia). Environ Earth Sci 59(6):1183-1193. doi:10.1007/s12665-0090107-4

Rakhmatullaev S, Huneau F, Kazbekov J, Celle-Jeanton H, MotelicaHeino M, Le Coustumer P, Jumanov J (2012) Groundwater resources of Uzbekistan: an environmental and operational overview. Cent Eur J Geosci 4(1):67-80. doi:10.2478/s13533-011-0062-y

Rakhmatullaev S, Huneau F, Celle-Jeanton H, Le Coustumer P, MotelicaHeino M, Bakiev M (2013) Water reservoirs, irrigation and sedimentation in Central Asia: a first-cut assessment for Uzbekistan. Environ Earth Sci 68(4):985-998. doi:10.1007/s12665-012-1802-0

Raska G, Kukolya J, Cserhati M, Krifaton C, Kriszt B (2009) The effects of DDT/DDD/DDE on soil microbes. Cereal Res Commun 37:585588

Reddy JM, Jumaboev K, Matyakubov B, Eshmuratov D (2013) Evaluation of furrow irrigation practices in Fergana Valley of 
Uzbekistan. Agric Water Manag 117:133-144. doi:10.1016/j.agwat. 2012.11.004

Reeves M (2012) Black work, green money: remittances, ritual, and domestic economies in southern Kyrgyzstan. Slavic Rev 71(1): 108. doi:10.5612/slavicreview.71.1.0108

Rehbein H, Molkentin J, Schubring R, Lieckfeldt D, Ludwig A (2008) Development of advanced analytical tools to determine the origin of caviar. J Appl Ichthyol 24:65-70. doi:10.1111/j.1439-0426.2008. 01091.x

Rehnus M, Mamadzhanov D, Venglovsky BI, Sorg JP (2013) The importance of agroforestry hay and walnut production in the walnut-fruit forests of southern Kyrgyzstan. Agrofor Syst 87(1):1-12. doi:10. 1007/s10457-012-9516-6

Reyers M, Pinto JG, Paeth H (2013) Statistical-dynamical downscaling of present day and future precipitation regimes in the aksu river catchment in Central Asia. Glob Planet Chang 107:36-49. doi:10.1016/j. gloplacha.2013.04.003

Richards CM, Volk GM, Reeves PA, Reilley AA, Henk AD, Forsline PL, Aldwinckle HS (2009) Selection of stratified core sets representing wild apple (Malus sieversii). J Am Soc Hortic Sci 134(2):228-235

Robinson S, Whitton M, Biber-Klemm S, Muzofirshoev N (2010) The impact of land-reform legislation on pasture tenure in GornoBadakhshan: from common resource to private property? Mt Res Dev 30(1):4-13. doi:10.1659/mrd-journal-d-09-00011.1

Rondelli B, Stride S, Garcia-Granero JJ (2013) Soviet military maps and archaeological survey in the Samarkand region. J Cult Herit 14(3): 270-276. doi:10.1016/j.culher.2012.06.006

Rosa RD, Paredes P, Rodrigues GC, Fernando RM, Alves I, Pereira LS, Allen RG (2012) Implementing the dual crop coefficient approach in interactive software: 2. Model testing. Agric Water Manag 103: 62-77. doi:10.1016/j.agwat.2011.10.018

Rowe WC (2009) "Kitchen gardens" in Tajikistan: the economic and cultural importance of small-scale private property in a post-soviet society. Hum Ecol 37(6):691-703. doi:10.1007/s10745-009-9278-6

Rudaya N, Tarasov P, Dorofeyuk N, Solovieva N, Kalugin I, Andreev A, Daryin A, Diekmann B, Riedel F, Tserendash N, Wagner M (2009) Holocene environments and climate in the Mongolian Altai reconstructed from the Hoton-Nur pollen and diatom records: a step towards better understanding climate dynamics in Central Asia. Quat Sci Rev Rev 28(5-6):540-554. doi:10.1016/j.quascirev.2008.10. 013

Rudenko I, Grote U, Lamers JPA, Martius C (2008) Add value, save water-increasing efficiency in the Uzbekistan cotton sector. Osteuropas 58(4-5):407

Rudenko I, Lamers JPA, Grote U (2009) Can Uzbek farmers get more for their cotton? Eur J Dev Res 21(2):283-296. doi:10.1057/ejdr.2009.3

Rudenko I, Bekchanov M, Djanibekov U, Lamers JPA (2013) The added value of a water footprint approach: micro- and macroeconomic analysis of cotton production, processing and export in water bound Uzbekistan. Glob Planet Chang 110:143-151. doi:10.1016/j. gloplacha.2013.09.007

Rukhovich DI, Pankova EI, Chernousenko GI, Koroleva PV (2010) Long-term salinization dynamics in irrigated soils of the Golodnaya Steppe and methods of their assessment on the basis of remote sensing data. Eurasian Soil Sci 43(6):682-692. doi:10.1134/ s 1064229310060098

Sanhueza-Pino K, Korup O, Hetzel R, Munack H, Weidinger JT, Dunning S, Ormukov C, Kubik PW (2011) Glacial advances constrained by ${ }^{10} \mathrm{Be}$ exposure dating of bedrock landslides, Kyrgyz Tien Shan. Quat Res 76(3):295-304. doi:10.1016/j.yqres. 2011.06.013

Saparov AS, Mirzakeev EK, Sharypova TM, Saparov GA, Abuduwaili J (2013) Irrigation erosion of irrigated soils in the foothills of southern Kazakhstan. J Arid Land 5(2):166-171. doi:10.1007/s40333-0130157-z
Scheer C, Wassmann R, Kienzler K, Ibragimov N, Lamers JPA, Martius $\mathrm{C}$ (2008a) Methane and nitrous oxide fluxes in annual and perennial land-use systems of the irrigated areas in the Aral Sea Basin. Glob Chang Biol 14(10):2454-2468. doi:10.1111/j.1365-2486.2008. 01631.x

Scheer C, Wassmann R, Klenzler K, Lbragimov N, Eschanov R (2008b) Nitrous oxide emissions from fertilized irrigated cotton (Gossypium hirsutum L.) in the Aral Sea Basin, Uzbekistan: influence of nitrogen applications and irrigation practices. Soil Biol Biochem 40(2): 290-301. doi:10.1016/j.soilbio.2007.08.007

Scheer C, Wassmann R, Butterbach-Bahl K, Lamers J, Martius C (2009) The relationship between $\mathrm{N}_{2} \mathrm{O}, \mathrm{NO}$, and $\mathrm{N}_{2}$ fluxes from fertilized and irrigated dryland soils of the Aral Sea Basin, Uzbekistan. Plant Soil 314(1-2):273-283. doi:10.1007/s11104-008-9728-8

Scheffran J, Battaglini A (2011) Climate and conflicts: the security risks of global warming. Reg Environ Chang 11:S27-S39. doi:10.1007/ s10113-010-0175-8

Schettler G, Oberhansli H, Stulina G, Mavlonov AA, Naumann R (2013) Hydrochemical water evolution in the Aral Sea Basin. J Hydrol 495: 267-284. doi:10.1016/j.jhydrol.2013.03.044

Schlogel R, Torgoev I, De Marneffe C, Havenith HB (2011) Evidence of a changing size-frequency distribution of landslides in the Kyrgyz Tien Shan, Central Asia. Earth Surf Process Landf 36(12):16581669. doi:10.1002/esp.2184

Schluter M, Herrfahrdt-Pahle E (2011) Exploring resilience and transformability of a river basin in the face of socioeconomic and ecological crisis: an example from the Amudarya river basin, Central Asia. Ecol Soc 16(1):19

Schluter M, Leslie H, Levin S (2009) Managing water-use trade-offs in a semi-arid river delta to sustain multiple ecosystem services: a modeling approach. Ecol Res 24(3):491-503. doi:10.1007/s11284-0080576-Z

Schluter M, Hirsch D, Pahl-Wostl C (2010) Coping with change: responses of the Uzbek water management regime to socioeconomic transition and global change. Environ Sci Policy 13(7): 620-636. doi:10.1016/j.envsci.2010.09.001

Schluter M, Khasankhanova G, Talskikh V, Taryannikova R, Agaltseva N, Joldasova I, Ibragimov R, Abdullaev U (2013) Enhancing resilience to water flow uncertainty by integrating environmental flows into water management in the Amudarya river, Central Asia. Glob Planet Chang 110:114-129. doi:10.1016/j.gloplacha.2013.05.007

Schmidt M, Doerre A (2011) Changing meanings of Kyrgyzstan's nut forests from colonial to post-Soviet times. Area 43(3):288-296. doi:10.1111/j.1475-4762.2010.00988.x

Scott J, Rosen MR, Saito L, Decker DL (2011) The influence of irrigation water on the hydrology and lake water budgets of two small aridclimate lakes in Khorezm, Uzbekistan. J Hydrol 410(1-2):114-125. doi:10.1016/j.jhydrol.2011.09.028

Shanafield M, Rosen M, Saito L, Chandra S, Lamers J, Nishonov B (2010) Identification of nitrogen sources to four small lakes in the agricultural region of Khorezm, Uzbekistan. Biogeochemistry 101(1-3):357-368. doi:10.1007/s10533-010-9509-3

Shiferaw B, Smale M, Braun HJ, Duveiller E, Reynolds M, Muricho G (2013) Crops that feed the world 10. Past successes and future challenges to the role played by wheat in global food security. Food Secur 5(3):291-317. doi:10.1007/s12571-013-0263-y

Shukurov N, Pen-Mouratov S, Steinberger Y, Kersten M (2009) Soil biogeochemical properties of Angren industrial area, Uzbekistan. J Soils Sediments 9(3):206-215. doi:10.1007/s11368-009-0079-8

Siegfried T, Bernauer T, Guiennet R, Sellars S, Robertson AW, Mankin J, Bauer-Gottwein P, Yakovlev A (2012) Will climate change exacerbate water stress in Central Asia? Clim Chang 112(3-4):881-899. doi:10.1007/s10584-011-0253-Z

Siegmund-Schultze M, Rischkowsky B, Yuldashev I, Abdalniyazov B, Lamers JPA (2013) The emerging small-scale cattle farming sector in Uzbekistan: highly integrated with crop production but suffering 
from low productivity. J Arid Environ 98:93-104. doi:10.1016/j. jaridenv.2013.08.001

Singh NJ, Grachev IA, Bekenov AB, Milner-Gulland EJ (2010a) Saiga antelope calving site selection is increasingly driven by human disturbance. Biol Conserv 143(7):1770-1779. doi:10.1016/j.biocon. 2010.04.026

Singh NJ, Grachev IA, Bekenov AB, Milner-Gulland EJ (2010b) Tracking greenery across a latitudinal gradient in central Asia - the migration of the saiga antelope. Divers Distrib 16(4):663-675. doi: 10.1111/j.1472-4642.2010.00671.x

Singh A, Seitz F, Schwatke C (2013) Application of multi-sensor satellite data to observe water storage variations. IEEE J Sel Top Appl Earth Observ Remote Sens 6(3):1502-1508. doi:10.1109/jstars.2013. 2258326

Sivanpillai R, Latchininsky AV (2008) Can late summer Landsat data be used for locating Asian migratory locust, Locusta migratoria migratoria, oviposition sites in the Amudarya River delta, Uzbekistan? Entomol Exp Appl 128(2):346-353. doi:10.1111/j. 1570-7458.2008.00719.x

Soja AJ, Groisman PY (2012) Northern Eurasia Earth Science Partnership Initiative: evolution of scientific investigations to applicable science. Environ Res Lett 7(4):5. doi:10.1088/1748-9326/7/4/ 045201

Sommer R, de Pauw E (2011) Organic carbon in soils of Central Asiastatus quo and potentials for sequestration. Plant Soil 338(1-2):273288. doi:10.1007/s11104-010-0479-y

Sommer R, Kienzler K, Conrad C, Ibragimov N, Lamers J, Martius C, Vlek P (2008) Evaluation of the CropSyst model for simulating the potential yield of cotton. Agron Sustain Dev 28(2):345-354. doi:10. 1051/agro:2008008

Sommer R, Glazirina M, Yuldashev T, Otarov A, Ibraeva M, Martynova L, Bekenov M, Kholov B, Ibragimov N, Kobilov R, Karaev S, Sultonov M, Khasanova F, Esanbekov M, Mavlyanov D, Isaev S, Abdurahimov S, Ikramov R, Shezdyukova L, de Pauw E (2013) Impact of climate change on wheat productivity in Central Asia. Agric Ecosyst Environ 178:78-99. doi:10.1016/j.agee.2013.06.011

Sorg A, Bolch T, Stoffel M, Solomina O, Beniston M (2012) Climate change impacts on glaciers and runoff in Tien Shan (Central Asia). Nat Clim Chang 2(10):725-731. doi:10.1038/nclimate1592

Spengler RN, Frachetti MD, Fritz GJ (2013) Ecotopes and herd foraging practices in the steppe/mountain ecotone of central Asia during the Bronze and Iron Ages. J Ethnobiol 33(1):125-147. doi:10.2993/ 0278-0771-33.1.125

Spivak L, Vitkovskaya I, Batyrbayeva M, Terekhov A (2012) The experience of land cover change detection by satellite data. Front Earth Sci 6(2):140-146. doi:10.1007/s11707-012-0317-z

Spoor M (2012) Agrarian reform and transition: what can we learn from 'the east'? J Peasant Stud 39(1):175-194. doi:10.1080/03066150. 2011.652949

Srebotnjak T, Hardi P (2011) Prospects for sustainable bioenergy production in selected former communist countries. Ecol Indic 11(5):10091019. doi:10.1016/j.ecolind.2010.12.018

Starodubtsev VM, Truskavetskiy SR (2011) Desertification processes in the Ili River delta under anthropogenic pressure. Water Resour 38(2):253-256. doi:10.1134/s0097807811010167

Stucker D, Kazbekov J, Yakubov M, Wegerich K (2012) Climate change in a small transboundary tributary of the Syr Darya calls for effective cooperation and adaptation. Mt Res Dev 32(3):275-285. doi:10. 1659/mrd-journal-d-11-00127.1

Stulina G, Eshchanov O (2013) Climate change impacts on hydrology and environment in the Pre-Aral region. Quat Int 311:87-96. doi:10. 1016/j.quaint.2013.07.015

Suntsov VV (2012) Origin of the plague microbe Yersinia pestis: structure of the process of speciation. Biol Bull 39(1):1-9. doi:10.1134/ s1062359012010104
Takata Y (2010) Analysis of spatial and temporal variation of soil organic carbon budget in northern Kazakhstan. Jarq - Jpn Agric Res Q 44(4): $335-342$

Takata Y, Funakawa S, Akshalov K, Ishida N, Kosaki T (2008a) Regional evaluation of the spatio-temporal variation in soil organic carbon dynamics for rainfed cereal farming in northern Kazakhstan. Soil Sci Plant Nutr 54(5):794-806. doi:10.1111/j.1747-0765.2007. 00298.x

Takata Y, Funakawa S, Yanai J, Mishima A, Akshalov K, Ishida N, Kosaki T (2008b) Influence of crop rotation system on the spatial and temporal variation of the soil organic carbon budget in northern Kazakhstan. Soil Sci Plant Nutr 54(1):159-171. doi:10.1111/j.17470765.2007.00217.x

Tavana M, Pirdashti M, Kennedy DT, Belaud JP, Behzadian M (2012) A hybrid Delphi-SWOT paradigm for oil and gas pipeline strategic planning in Caspian Sea basin. Energy Policy 40:345-360. doi:10. 1016/j.enpol.2011.10.020

Teasley RL, McKinney DC (2011) Calculating the benefits of transboundary river basin cooperation: Syr Darya Basin. J Water Resour Plan Manag-ASCE 137(6):481-490. doi:10.1061/(asce)wr. 1943-5452.0000141

Terasawa Y, Takata K, Hirano H, Kato K, Kawahara T, Sasakuma T, Sasanuma T (2011) Genetic variation of high-molecular-weight glutenin subunit composition in Asian wheat. Genet Resour Crop Evol 58(2):283-289. doi:10.1007/s10722-010-9573-5

Terraube J, Arroyo BE, Mougeot F, Madders M, Watson J, Bragin EA (2009) Breeding biology of the Pallid harrier Circus macrourus in North-Central Kazakhstan: implications for the conservation of a near threatened species. Oryx 43(1):104-112. doi:10.1017/ s0030605307000683

Thenkabail PS, Wu ZT (2012) An automated cropland classification algorithm (ACCA) for Tajikistan by combining Landsat, MODIS, and secondary data. Remote Sens 4(10):2890-2918. doi:10.3390/ rs4102890

Thenkabail PS, Mariotto I, Gumma MK, Middleton EM, Landis DR, Huemmrich KF (2013) Selection of Hyperspectral Narrowbands (HNBs) and composition of Hyperspectral Twoband Vegetation Indices (HVIs) for biophysical characterization and discrimination of crop types using field reflectance and Hyperion/EO-1 data. IEEE J Sel Top Appl Earth Observ Remote Sens 6(2):427-439. doi:10. 1109/jstars.2013.2252601

Thevs N, Zerbe S, Kyosev Y, Rozi A, Tang B, Abdusalih N, Novitskiy Z (2012) Apocynum venetum L. and Apocynum pictum Schrenk (Apocynaceae) as multi-functional and multi-service plant species in Central Asia: a review on biology, ecology, and utilization. J Appl Bot Food Qual 85(2):159-167

Thorpe A, Van Anrooy R (2010) Strategies for the rehabilitation of the inland fisheries sector in Central Asia. Fish Manag Ecol 17(2):134 140. doi:10.1111/j.1365-2400.2009.00699.x

Thorpe A, van Anrooy R, Niyazov BN, Sarieva MK, Valbo-Jorgensen J, Millar AM (2009) The collapse of the fisheries sector in Kyrgyzstan: an analysis of its roots and its prospects for revival. Communist Post-Communist Stud 42(1):141-163. doi:10.1016/j.postcomstud. 2009.02.007

Tischbein B, Manschadi AM, Hornidge AK, Conrad C, Lamers JPA, Oberkircher L, Schorcht G, Vlek PLG (2011) Proposals for the more efficient utilization of water resources in the province of Khorezm, Uzbekistan. Hydrol Wasserbewirtsch 55(2):116-125

Tischbein B, Manschadi AM, Conrad C, Hornidge AK, Bhaduri A, Ul Hassan M, Lamers JPA, Awan UK, Vlek PLG (2013) Adapting to water scarcity: constraints and opportunities for improving irrigation management in Khorezm, Uzbekistan. Water Sci Technol-Water Supply 13(2):337-348. doi:10.2166/ws.2013.028

Toderich KN, Shuyskaya EV, Ismail S, Gismatullina LG, Radjabov T, Bekchanov BB, Aralova DB (2009) Phytogenic resources of halophytes of Central Asia and their role for rehabilitation of sandy 
desert degraded rangelands. Land Degrad Dev 20(4):386-396. doi: 10.1002/ldr.936

Toleubayev K, Jansen K, van Huis A (2010) Knowledge and agrarian decollectivisation in Kazakhstan. J Peasant Stud 37(2):353-377. doi: 10.1080/03066151003595069

Toleubayev K, Jansen K, Van Huis A (2011) From integrated pest management to indiscriminate pesticide use in Kazakhstan. J Sustain Agric 35(4):350-375. doi:10.1080/10440046.2011.562036

Tornqvist R, Jarsjo J (2012) Water savings through improved irrigation techniques: basin-scale quantification in semi-arid environments. Water Resour Manag 26(4):949-962. doi:10.1007/s11269-0119819-9

Tornqvist R, Jarsjo J, Karimov B (2011) Health risks from large-scale water pollution: trends in Central Asia. Environ Int 37(2):435-442. doi:10.1016/j.envint.2010.11.006

Toth JP, Varga Z (2011) Inter- and intraspecific variation in the genitalia of the 'Melitaea phoebe group' (Lepidoptera, Nymphalidae). Zool Anz 250(3):258-268. doi:10.1016/j.jcz.2011.05.002

Tynybaeva TG, Kostina NV, Terekhov AM, Kurakov AV (2008) The microbiological activity and toxicity of oil-polluted playa solonchaks and filled grounds within the Severnye Buzachi Oil Field (Kazakhstan). Eurasian Soil Sci 41(10):1115-1123. doi:10.1134/ s1064229308100141

Umbanhowar CE, Shinneman ALC, Tserenkhand G, Hammon ER, Lor P, Nail K (2009) Regional fire history based on charcoal analysis of sediments from nine lakes in western Mongolia. The Holocene 19(4):611-624. doi:10.1177/0959683609104039

Unger-Shayesteh K, Vorogushyn S, Farinotti D, Gafurov A, Duethmann D, Mandychev A, Merz B (2013) What do we know about past changes in the water cycle of Central Asian headwaters? A review. Glob Planet Chang 110:4-25. doi:10.1016/j.gloplacha.2013.02.004

Usubaliev B, Brantestam AK, Salomon B, Garkava-Gustavson L, von Bothmer R (2013) Genetic diversity in farmer grown spring barley material from Kyrgyzstan. Genet Resour Crop Evol 60(6):18431858. doi:10.1007/s10722-013-9959-2

van Assche K, Djanibekov N (2012) Spatial planning as policy integration: the need for an evolutionary perspective. Lessons from Uzbekistan. Land Use Policy 29(1):179-186. doi:10.1016/j. landusepol.2011.06.004

Van Atta D (2009) "White gold" or fool's gold? The political economy of cotton in Tajikistan. Probl Post-Communism 56(2):17-35. doi:10. 2753/pp c1075-8216560202

Vanselow KA, Kraudzun T, Samimi C (2012) Grazing practices and pasture tenure in the eastern Pamirs the nexus of pasture use, pasture potential, and property rights. Mt Res Dev 32(3):324-336. doi:10. 1659/mrd-journal-d-12-00001.1

Veldwisch GJA, Mollinga PP (2013) Lost in transition? The introduction of water users associations in Uzbekistan. Water Int 38(6):758-773. doi:10.1080/02508060.2013.833432

Veldwisch GJ, Spoor M (2008) Contesting rural resources: emerging 'forms' of agrarian production in Uzbekistan. J Peasant Stud 35(3): 424-451. doi:10.1080/03066150802340420

Vintro LL, Mitchell PI, Omarova A, Burkitbayev M, Napoles HJ, Priest ND (2009) Americium, plutonium and uranium contamination and speciation in well waters, streams and atomic lakes in the Sarzhal region of the Semipalatinsk Nuclear Test Site, Kazakhstan. J Environ Radioact 100(4):308-314. doi:10.1016/j.jenvrad.2008.12. 009

von der Dunk A, Schmidt M (2010) Flourishing retail in the post-soviet sphere? Potentials and constraints of small-scale retail activities in rural Kyrgyzstan. Communist Post-Communist Stud 43(2):233243. doi:10.1016/j.postcomstud.2010.03.006

Vyshpolsky F, Qadir M, Karimov A, Mukhamedjanov K, Bekbaev U, Paroda R, Aw-Hassan A, Karajeh F (2008) Enhancing the productivity of high-magnesium soil and water resources in Central Asia through the application of phosphogypsum. Land Degrad Dev 19(1):45-56. doi:10.1002/ldr.814

Vyshpolsky F, Mukhamedjanov K, Bekbaev U, Ibatullin S, Yuldashev T, Noble AD, Mirzabaev A, Aw-Hassan A, Qadir M (2010) Optimizing the rate and timing of phosphogypsum application to magnesium-affected soils for crop yield and water productivity enhancement. Agric Water Manag 97(9):1277-1286. doi:10.1016/j. agwat.2010.02.020

Wagner V (2009) Eurosiberian meadows at their southern edge: patterns and phytogeography in the NW Tien Shan. J Veg Sci 20(2):199 208. doi:10.1111/j.1654-1103.2009.01032.x

Wagner V, Durka W, Hensen I (2011) Increased genetic differentiation but no reduced genetic diversity in peripheral vs. central populations of a steppe grass. Am J Bot 98(7):1173-1179. doi:10.3732/ajb. 1000385

Wandel J, Pieniadz A, Glauben T (2011) What is success and what is failure of transition? A critical review of two decades of agricultural reform in the Europe and Central Asia region. Post-Communist Econ 23(2):139-162. doi:10.1080/14631377.2011.570037

Webber HA, Madramootoo CA, Bourgault M, Horst MG, Stulina G, Smith DL (2008) Plant and soil water dynamics of alternate furrow and regulated deficit irrigation for two legume crops. Trans ASABE 51(4):1341-1350

Webber H, Madramootoo C, Bourgault M, Horst M, Stulina G, Smith D (2009) Response of two legume crops to soil salinity in gypsiferous soils. Irrig Drain 58(5):586-595. doi:10.1002/ird.448

Webber HA, Madramootoo CA, Bourgault M, Horst MG, Stulina G, Smith DL (2010) Adapting the CROPGRO model for saline soils: the case for a common bean crop. Irrig Sci 28(4):317-329. doi:10. 1007/s00271-009-0189-5

Wegerich K (2008a) Blueprints for water user associations' accountability versus local reality: evidence from south Kazakhstan. Water Int 33(1):43-54. doi:10.1080/02508060801928034

Wegerich K (2008b) Hydro-hegemony in the Amu Darya Basin. Water Policy 10:71-88. doi:10.2166/wp.2008.208

Wegerich K (2009) Shifting to hydrological boundaries - the politics of implementation in the lower Amu Darya Basin. Phys Chem Earth 34(4-5):279-288. doi:10.1016/j.pce.2008.06.003

Wegerich K, Kazbekov J, Kabilov F, Mukhamedova N (2012a) Mesolevel cooperation on transboundary tributaries and infrastructure in the Ferghana Valley. Int J Water Resour Dev 28(3):525-543. doi:10. 1080/07900627.2012.684314

Wegerich K, Kazbekov J, Mukhamedova N, Musayev S (2012b) Is it possible to shift to hydrological boundaries? The Ferghana Valley meshed system. Int J Water Resour Dev 28(3):545-564. doi:10. 1080/07900627.2012.684316

Wichelns D (2010) Embracing uncertainty to improve water management, with examples from seven river basins. Int $\mathrm{J}$ Water Resour Dev 26(3):495-508. doi:10.1080/07900627.2010.489304

Wiedemann C, Salzmann S, Mirshakarov I, Volkmer H (2012) Thermal insulation in high mountainous regions a case study of ecological and socioeconomic impacts in the Eastern Pamirs, Tajikistan. Mt Res Dev 32(3):294-303. doi:10.1659/mrd-journal-d-11-00093.1

Wilschut LI, Addink EA, Heesterbeek H, Heier L, Laudisoit A, Begon M, Davis S, Dubyanskiy VM, Burdelov LA, de Jong SM (2013) Potential corridors and barriers for plague spread in Central Asia. Int J Health Geogr 12:15. doi:10.1186/1476-072x-12-49

Windhorst HW (2009) Recent patterns of egg production and trade: a status report on a regional basis. Worlds Poult Sci J 65(4):685707. doi:10.1017/s0043933909000476

Wright CK, de Beurs KM, Henebry GM (2012) Combined analysis of land cover change and NDVI trends in the Northern Eurasian grain belt. Front Earth Sci 6(2):177-187. doi:10.1007/s11707-012-0327-x

Xu XK, Kleidon A, Miller L, Wang SQ, Wang LQ, Dong GC (2010) Late Quaternary glaciation in the Tianshan and implications for 
palaeoclimatic change: a review. Boreas 39(2):215-232. doi:10. $1111 / j .1502-3885.2009 .00118 . x$

Yakubov M (2012a) Assessing irrigation performance from the farmers' perspective: a qualitative study. Irrig Drain 61(3):316-329. doi:10. 1002/ird.649

Yakubov M (2012b) A programme theory approach in measuring impacts of irrigation management transfer interventions: the case of Central Asia. Int J Water Resour Dev 28(3):507-523. doi:10.1080/ 07900627.2012.684313

Yakubov M, Manthrithilake H (2009) Water for food as food for thought: case study of applying the PODIUMSim model to Uzbekistan. Irrig Drain 58(1):17-37. doi:10.1002/ird.451

Yerzhanova S, Huszti Z (2013) Conditions and opportunities of environment management of a problematic lake: possible control over the change of the natural condition of the Ilibalkhash basin. Carpath J Earth and Environ Sci 8(4):115-124

Yousefkhani SSH, Ficetola GF, Rastegar-Pouyani N, Ananjeva NB, Rastegar-Pouyani E, Masroor R (2013) Environmental suitability and distribution of the Caucasian rock agama, Paralaudakia caucasia (Sauna: Agamidae) in Western and Central Asia. Asian Herpetol Res 4(3):207-213. doi:10.3724/sp.j.1245.2013.00207

Yuldasheva NK, Ul'chenko NT, Bekker NP, Chernenko TV, Glushenkova AI, Mustaev FA, Ionov MV, Heuer B (2011a) Oil content and lipid composition of safflower (Carthamus tinctorius) irrigated with saline water under greenhouse and field conditions. Ann Appl Biol 159(2):169-177. doi:10.1111/j.1744-7348.2011.00490.x

Yuldasheva NK, Ul'chenko NT, Bekker NP, Chernenko TV, Skosyreva OV, Glushenkova AI, Heuer B (2011b) Lipids from Crambe amabilis and C. kotschyana seeds grown with saline irrigation water. Chem Nat Compd 46(6):866-868. doi:10.1007/s10600-011-9770-2

Yuldasheva NK, Ul'chenko NT, Bekker NP, Chernenko TV, Skosyreva OV, Glushenkova AI, Mustaev FA, Ionov MV, Heuer B (2011c) Influence of irrigation-water salinity on lipids of Crambe abyssinica seeds. Chem Nat Compd 46(6):862-865. doi:10.1007/s10600-0119769-8

Zakhirova L (2013) The international politics of water security in Central Asia. Eur-Asia Stud 65(10):1994-2013. doi:10.1080/09668136. 2013.848647

Zaton M (2008) Taxonomy and palaeobiology of the Bathonian (Middle Jurassic) tulitid ammonite Morrisiceras. Geobios 41(5):699-717. doi:10.1016/j.geobios.2007.11.001

Zhanar K, Tanatarov AD, Soltan ME, Sambetbaev AA (2012) Performance of some productive traits of broiler chickens as affected by different landing in closed houses. J Anim Vet Adv 11(19):3609_ 3612

Zhang YJ, Stock M, Zhang P, Wang XL, Zhou H, Qu LH (2008) Phylogeography of a widespread terrestrial vertebrate in a barelystudied Palearctic region: green toads (Bufo viridis subgroup) indicate glacial refugia in Eastern Central Asia. Genetica 134(3):353365. doi:10.1007/s10709-008-9243-0

Zhao Z, Huang X, Xu J (2013) The effects of irrigation on wheat yield on a global scale. Appl Eng Agric 29(3):335-342. doi:10.13031/aea. 29.9336

Zhou DC, Luo GP, Lu L (2010) Processes and trends of the land use change in Aksu watershed in the central Asia from 1960 to 2008. J Arid Land 2(3):157-166. doi:10.3724/sp.j.1227.2010.00157 